Published in final edited form as:

J Am Chem Soc. 2006 December 6; 128(48): 15517-15528.

\title{
Zinspy Sensors with Enhanced Dynamic Range for Imaging Neuronal Cell Zinc Uptake and Mobilization
}

\author{
Elizabeth M. Nolan ${ }^{\prime}$, Jubin W. Ryu§, Jacek Jaworski§, $\|, \#$, Rodney P. Feazell ${ }^{\dagger}$, Morgan \\ Sheng $\$, \perp, \|$, and Stephen J. Lippard ${ }^{\star}, \dagger$ \\ Contribution from the Department of Chemistry, Picower Institute of Learning and Memory, RIKEN- \\ MIT Neuroscience Research Center, and Howard Hughes Medical Institute, Massachusetts Institute \\ of Technology, Cambridge, Massachusetts 02139, and Laboratory of Molecular and Cellular \\ Neurobiology, International Institute of Molecular and Cell Biology, 02-109 Warsaw, Poland
}

\begin{abstract}
Thiophene moieties were incorporated into previously described Zinspy (ZS) fluorescent Zn(II) sensor motifs (Nolan, E. M.; Lippard, S. J. Inorg. Chem. 2004, 43, 8310-8317) to provide enhanced fluorescence properties, low-micromolar dissociation constants for $\mathrm{Zn}$ (II), and improved $\mathrm{Zn}$ (II) selectivity. Halogenation of the xanthenone and benzoate moieties of the fluorescein platform systematically modulates the excitation and emission profiles, $\mathrm{pH}$-dependent fluorescence, $\mathrm{Zn}$ (II) affinity, and $\mathrm{Zn}$ (II) complexation rates, offering a general strategy for tuning multiple properties of xanthenone-based metal ion sensors. Extensive biological studies in cultured cells and primary neuronal cultures demonstrate 2-\{6-hydroxy-3-oxo-4,5-bis[(pyridin-2-ylmethylthiophen-2ylmethylamino)methyl]-3H-xanthen-9-yl $\}$ benzoic acid (ZS5) to be a versatile imaging tool for detecting $\mathrm{Zn}$ (II) in vivo. ZS5 localizes to the mitochondria of HeLa cells and allows visualization of glutamate-mediated $\mathrm{Zn}$ (II) uptake in dendrites and $\mathrm{Zn}$ (II) release resulting from nitrosative stress in neurons.
\end{abstract}

\section{Introduction}

The neurobiology of zinc has attracted significant attention. ${ }^{1,2}$ Zinc is the second most abundant d-block metal ion in the human brain, with relatively high concentrations found in the hippocampus and neocortex. ${ }^{3}$ Of particular interest to this work is zinc found in the hippocampus, a region of the mammalian forebrain involved in learning and memory formation. This zinc can be divided into two types, ${ }^{4}$ protein bound and loosely bound, the latter also termed histochemically observable, chelatable, or mobile. ${ }^{5}$ Hippocampal loosely bound zinc is housed in the synaptic vesicles of glutamatergic mossy fiber neurons. Co-localization of zinc and glutamate in this subset of synaptic vesicles was assumed for decades, but proof of such mutual uptake was provided only recently. 6

Many studies point to the importance of $\mathrm{Zn}$ (II) in human neurophysiology. Multiple neuromodulatory effects for $\mathrm{Zn}$ (II) have been documented and include down-regulation of $\mathrm{N}$ methyl-D-aspartate receptors, ${ }^{7-10}$ one major type of glutamatergic ion channel in the

E-mail: lippard@mit.edu

$\dagger$ Department of Chemistry, MIT.

\$Picower Institute of Learning and Memory, MIT.

${ }^{\perp}$ RIKEN-MIT Neuroscience Research Center.

$\|_{\text {Howard Hughes Medical Institute. }}$

\#International Institute of Molecular and Cell Biology, Poland.

Supporting Information Available: Tables S1 and S2, Scheme S1, Figures S1-S12, CIF files, experimental details for X-ray crystallographic modeling studies and cytotoxicity assays in dentate gyrus neurons, representative ${ }^{1} \mathrm{H}$ NMR spectra, and IR spectral data for all probes. This material is available free of charge via the Internet at http://pubs.acs.org. 
mammalian central nervous system, and inhibition of $\mathrm{Ca}(\mathrm{II})$ channels. ${ }^{11} \mathrm{Zinc}$ has also been implicated in long-term potentiation (LTP), an electrophysiological phenomenon thought to underlie certain forms of learning and memory, in DG $\rightarrow$ CA3 synapses. ${ }^{12}$ Despite these observations, the concept of vesicular zinc release into the synapse remains controversial. ${ }^{13-}$ 19

Zinc pathology is also an area of current interest. High concentrations of $\mathrm{Zn}$ (II) are neurotoxic. A number of zinc transporter proteins ${ }^{20,21}$ and metallothionein 22,23 maintain zinc homeostasis under normal physiological conditions, but these mechanisms can fail during periods of stress. Uncontrolled zinc release occurs from protein-bound and vesicular stores following blunt head trauma and as a result of stroke or seizure, and it is implicated in subsequent neurodegeneration. ${ }^{24-29}$ Evidence exists for a role of $\mathrm{Zn}(\mathrm{II})$ in the onset and pathogenesis of Alzheimer's disease. ${ }^{30}$ There are several mechanisms to explain $\mathrm{Zn}$ (II) neurotoxicity, including rapid influx into mitochondria, which triggers apoptosis following uncontrolled release. ${ }^{28,31}$ Of particular relevance to some of the work described here is the growing link between $\mathrm{Zn}(\mathrm{II})$ toxicity and oxidative stress. ${ }^{27,31,32}$

Despite this knowledge, many details regarding the functional significance of $\mathrm{Zn}$ (II) in neurobiology remain elusive. This situation has motivated the design of many new Zn(II) imaging tools suitable for studies in living cells. Initially, aryl sulfonamide-based sensors, including $N$-(6-methoxy-8-quinolyl)-p-toluenesulfonamide (TSQ) and its derivatives, were employed to visualize chelatable $\mathrm{Zn}$ (II) in the mammalian hippocampus and in live cells. ${ }^{33-}$ 36 Over the past six years, in part guided by tactics used for $\mathrm{Ca}(\mathrm{II})$ sensing, 37 significant advances in biological $\mathrm{Zn}$ (II) sensor design have been made ${ }^{2,38-41}$ Many sensors, including the ACF, ${ }^{42} \mathrm{ZnAF},{ }^{43,44}$ Fluo- and Rhod-Zn, ${ }^{45,46} \mathrm{Zinpyr},{ }^{47-49}$ and QZ ${ }^{50}$ probes, provide visible excitation and bright fluorescence in the $\mathrm{Zn}$ (II)-bound forms. Some of these sensors have been employed in studies of $\mathrm{Zn}$ (II) neurobiology. $17,44,49,50$ Small-molecule ratiometric $\mathrm{Zn}$ (II) sensors have been documented, ${ }^{46,51-55}$ several of which have been applied in vivo. 53,54 Protein-based $56-59$ approaches have also emerged as useful $\mathrm{Zn}(\mathrm{II})$ sensing tools, and several peptide-based ${ }^{60-62}$ strategies have been reported. Nevertheless, the design and implementation of new $\mathrm{Zn}(\mathrm{II})$ imaging reagents is required to continue advances in this field. Several recent initiatives $44,50,63$ address the need for $\mathrm{Zn}$ (II) sensors with varying affinities for use in vivo, since estimated endogenous $\mathrm{Zn}$ (II) concentrations vary widely, depending on the tissue or cell type under study.

We previously reported the Zinpyr (ZP) $)^{47-49}$ and Zinspy (ZS) ${ }^{64}$ families of Zn(II) sensors, several of which are depicted in Figure 1. The thioether-for-pyridyl substitution that gives the ZS sensors was made with the aims of lowering $\mathrm{Zn}$ (II) affinity and potentially modulating metal-ion selectivity relative to the parent ZP compounds, which employ the di(2-picolyl) amine (DPA) chelate. Although the ZS probes exhibit improved Zn(II) selectivity and lower affinity $\mathrm{Zn}$ (II) binding as compared to their DPA-based counterparts, they generally suffer from relatively poor photophysical properties, including high background fluorescence and weak ( $\leq 2$-fold) fluorescence enhancement with $\mathrm{Zn}$ (II) coordination, at least for the tertiary amine-based systems. These features preclude facile application of these sensors for biological imaging of $\mathrm{Zn}(\mathrm{II})$.

In the present article, we describe Zinspy sensors with enhanced dynamic range. On the basis of several observations from our laboratory and a recent literature report that indicates groups distant from a fluorophore contribute to PET quenching, 65 we reasoned that incorporating multiple aromatic heterocycles in a tertiary amine-based ligand is important for achieving relatively low background fluorescence and good Zn(II)-induced fluorescence turn-on, at least for symmetrical probes such as ZP1 and ZS1. Substitution of the thioether moiety in ZS1 or ZS2 with a thiophene group is one way to accomplish this task. Moreover, because thiophenes 
are less basic than pyridyl groups and thioethers, we anticipated that the thiophene moiety would be non-coordinating. The resulting $\mathrm{N}_{2} \mathrm{O}$ donor set for $\mathrm{Zn}$ (II) binding would confer lower affinity $\mathrm{Zn}$ (II) coordination than the $\mathrm{N}_{3} \mathrm{O}$ donor sets of the symmetrical $\mathrm{ZP}$ systems. In accord with these expectations, the thiophene-for-thioether/pyridine subsitution affords lowmicromolar $\mathrm{Zn}$ (II) $K_{\mathrm{d}}$ values, improved $\mathrm{Zn}$ (II) selectivity, and fluorescence enhancements suitable for biological imaging. We describe extensive confocal microscopic studies of ZS5 (Scheme 1) in cultured cells and in primary cultures of neurons. ZS5 illuminates the mitochondria in HeLa cells, affords a visual image of glutamate-dependent $\mathrm{Zn}$ (II) uptake in dendrites of hippocampal neurons, and detects endogenous $\mathrm{Zn}$ (II) release in dentate gyrus neurons resulting from nitrosative stress. These findings indicate that ZS5 is a versatile $\mathrm{Zn}$ (II) imaging tool with great potential for biological use.

\section{Experimental Section}

\section{Reagents}

Acetonitrile was dried using columns of aluminum oxide, and anhydrous 1,2-dichloroethane (DCE) was purchased from Aldrich. Methanol was filtered through an aluminum oxide plug before use. Ligand $\mathbf{1}^{66}$ and $4^{\prime}, 5^{\prime}$-fluorescein dicarboxaldehyde (2) ${ }^{47}$ were prepared as previously described. $2^{\prime}, 7^{\prime}$-Difluorofluorescein was purchased from Invitrogen and 2', $7^{\prime}$ dichlorofluorescein from Aldrich. The latter was recrystallized from boiling EtOH before use. All other halogenated fluorescein derivatives were prepared by acid-catalyzed condensation of the appropriate resorcinol and substituted phthalic anhydride. Additional reagents were obtained from Aldrich and used as received.

\section{Materials and Methods}

Merck F254 silica gel plates were used for analytical TLC and were visualized with UV light. Preparative TLC was performed on Whatman silica gel-60 plates of $1 \mathrm{~mm}$ thickness, manufactured by EM Science. NMR spectra were acquired on a Varian 300 or $500 \mathrm{MHz}$ spectrophotometer operating at ambient probe temperature, $283 \mathrm{~K}$. The spectra were referenced to internal standards. An Avatar FTIR instrument was used to obtain IR spectra, and the data are included as Supporting Information. High-resolution mass spectra were collected by staff at the MIT Department of Chemistry Instrumentation Facility.

\section{2-\{6-Hydroxy-3-oxo-4,5-bis[(pyridin-2-ylmethylthiophen-2-yl-methylamino)methyl]-3H- xanthen-9-yl\} benzoic Acid (3, Zinspy-5, ZS5)}

A portion of fluorescein $2(50 \mathrm{mg}, 0.13 \mathrm{mmol})$ was dissolved in $5 \mathrm{~mL}$ of DCE, and $30 \mu \mathrm{L}$ of HOAc was added. Compound 1 (77 mg, $0.38 \mathrm{mmol}$ ) was dissolved in $5 \mathrm{~mL}$ of DCE and added to the fluorescein solution in a dropwise manner. The cloudy and orange reaction mixture was stirred for $1 \mathrm{~h}$ at room temperature. A portion of $\mathrm{NaB}(\mathrm{OAc})_{3} \mathrm{H}(70 \mathrm{mg}, 0.33 \mathrm{mmol})$ was added, and the solution clarified. The reaction was stirred overnight at room temperature and became orange-brown. The solution was diluted with $15 \mathrm{~mL}$ of $\mathrm{CHCl}_{3}$ and washed with water $(3 \times 15$ $\mathrm{mL}$ ). The organic portion was dried over $\mathrm{MgSO}_{4}$, and the solvent was removed in vacuo, which gave an orange solid. Preparative TLC on silica gel $\left(20: 1 \mathrm{CHCl}_{3} / \mathrm{MeOH}\right)$ gave the product as an orange-red powder $(37 \mathrm{mg}, 38 \%) ; \mathrm{mp}>280{ }^{\circ} \mathrm{C}$, dec. TLC: $R_{f}=0.59$ (silica, 9:1 $\mathrm{CHCl}_{3} /$ $\mathrm{MeOH}) .{ }^{1} \mathrm{H}$ NMR $\left(\mathrm{CD}_{3} \mathrm{OD}, 300 \mathrm{MHz}\right): \delta 3.90(4 \mathrm{H}, \mathrm{q}), 4.06(4 \mathrm{H}, \mathrm{m}), 4.15(4 \mathrm{H}, \mathrm{m}), 6.59(2 \mathrm{H}$, d), $6.90(4 \mathrm{H}, \mathrm{m}), 7.05(2 \mathrm{H}, \mathrm{m}), 7.12(1 \mathrm{H}, \mathrm{d}), 7.17(2 \mathrm{H}, \mathrm{t}), 7.25(2 \mathrm{H}, \mathrm{d}), 7.56(4 \mathrm{H}, \mathrm{m}), 7.65(2 \mathrm{H}$, t), $8.00(1 \mathrm{H}, \mathrm{d}), 8.35(2 \mathrm{H}, \mathrm{d})$. HRMS (ESI): calcd $[\mathrm{M}+\mathrm{Na}]^{+}, 787.2019$; found, 787.2024. 


\section{2-\{2,7-Dichloro-6-hydroxy-3-oxo-4,5-bis[(pyridin-2-ylmethyl-thiophen-2-ylmethylamino) methyl]-3H-xanthen-9-yl\} benzoic Acid (4, Zinspy-6, ZS6)}

Portions of $1(200 \mathrm{mg}, 0.979 \mathrm{mmol})$ and $\left(\mathrm{CH}_{2} \mathrm{O}\right)_{n}(50 \mathrm{mg}, 1.7 \mathrm{mmol})$ were combined in $5 \mathrm{~mL}$ of $\mathrm{MeCN}$ and heated to reflux for $45 \mathrm{~min}$. A slurry of 2',7'-dichlorofluorescein (131 mg, 0.327 $\mathrm{mmol}$ ) in $7 \mathrm{~mL}$ of $1: 1 \mathrm{MeCN} / \mathrm{H}_{2} \mathrm{O}$ was added to the reaction, and the solution turned pink. The reaction was heated to reflux for $22 \mathrm{~h}$, during which time a pink precipitate formed, and cooled. The mixture was filtered, and the precipitate was washed with $15 \mathrm{~mL}$ of $\mathrm{Et}_{2} \mathrm{O}$. The pure product was obtained as a light pink powder after recrystallization twice from boiling EtOH $(223 \mathrm{mg}$, $85 \%) ; \mathrm{mp}=200-201{ }^{\circ} \mathrm{C} .{ }^{1} \mathrm{H}$ NMR (DMSO- $\left.d_{6}, 300 \mathrm{MHz}\right): \delta 3.96(8 \mathrm{H}, \mathrm{m}), 4.08(4 \mathrm{H}, \mathrm{s}), 6.56$ $(2 \mathrm{H}, \mathrm{s}), 6.96(4 \mathrm{H}, \mathrm{m}), 7.33-7.43(8 \mathrm{H}, \mathrm{m}), 7.74-7.87(5 \mathrm{H}, \mathrm{m}), 7.99(1 \mathrm{H}, \mathrm{d}), 8.59(2 \mathrm{H}, \mathrm{d})$. HRMS (ESI): calcd [M-H] $]^{-}, 831.1264$; found, 831.1265.

\section{2-\{2,7-Difluoro-6-hydroxy-3-oxo-4,5-bis[(pyridin-2-ylmethyl-thiophen-2-ylmethylamino) methyl]-3H-xanthen-9-yl\} benzoic Acid (5, Zinspy-7, ZS7)}

Portions of $1(83 \mathrm{mg}, 0.41 \mathrm{mmol})$ and $\left(\mathrm{CH}_{2} \mathrm{O}\right)_{n}(13 \mathrm{mg}, 0.45 \mathrm{mmol})$ were combined in $5 \mathrm{~mL}$ of $\mathrm{MeCN}$ and heated to reflux for $1 \mathrm{~h}$. A slurry of 2',7'-difluorofluorescein $(50 \mathrm{mg}, 0.14 \mathrm{mmol})$ in $10 \mathrm{~mL}$ of $1: 1 \mathrm{MeCN} / \mathrm{H}_{2} \mathrm{O}$ was added to the reaction, and the solution turned orange. The reaction was heated to reflux for $22 \mathrm{~h}$, and a light pink precipitate formed. The reaction was cooled to room temperature and filtered, and the precipitate was recrystallized from boiling EtOH twice ( $71 \mathrm{mg}, 60 \%$ ); $\mathrm{mp}=182-183{ }^{\circ} \mathrm{C} .{ }^{1} \mathrm{H}$ NMR (DMSO- $d_{6}$ with NaOD, $300 \mathrm{MHz}$ ): $\delta$ $3.74(4 \mathrm{H}, \mathrm{s}), 3.91(8 \mathrm{H}, \mathrm{m}), 6.26(2 \mathrm{H}, \mathrm{d}), 6.88-7.00(5 \mathrm{H}, \mathrm{m}), 7.13(2 \mathrm{H}, \mathrm{m}), 7.31(2 \mathrm{H}, \mathrm{d}), 7.44$ $(2 \mathrm{H}, \mathrm{qd}), 7.64(4 \mathrm{H}, \mathrm{m}), 7.98(1 \mathrm{H}, \mathrm{dd}), 8.36(2 \mathrm{H}, \mathrm{d})$. HRMS (ESI): calcd [M-H] $]^{-}, 799.1855$; found, 799.1866.

\section{2-\{2,7-Dichloro-6-hydroxy-3-oxo-4,5-bis[(pyridin-2-ylmethylthiophen-2-ylmethylamino) methyl]-3H-xanthen-9-yl\}-3,4,5,6-tetrachloro-benzoic Acid (6, Zinspy-Cl6, ZSCI6)}

Portions of $1(200 \mathrm{mg}, 0.979 \mathrm{mmol})$ and $\left(\mathrm{CH}_{2} \mathrm{O}\right)_{n}(48 \mathrm{mg}, 1.7 \mathrm{mmol})$ were combined in $5 \mathrm{~mL}$ of $\mathrm{MeCN}$ and heated to reflux for $1 \mathrm{~h}$. A slurry of 2',3,4,5,6,7'-hexachlorofluorescein in $10 \mathrm{~mL}$ of $1: 1 \mathrm{MeCN} / \mathrm{H}_{2} \mathrm{O}$ was added to the reaction, and the solution turned deep magenta. The reaction was heated to reflux for $22 \mathrm{~h}$ (during which time a pink precipitate formed), cooled, and filtered. The precipitate was washed with $10 \mathrm{~mL}$ of $\mathrm{MeCN}$ and recrystallized twice from boiling EtOH, which afforded a light pink powder $(255 \mathrm{mg}, 80 \%) ; \mathrm{mp}=216-217^{\circ} \mathrm{C} .{ }^{1} \mathrm{H}$ NMR (DMSO- $\left.d_{6}, 300 \mathrm{MHz}\right): \delta 3.95(8 \mathrm{H}, \mathrm{s}), 4.05(4 \mathrm{H}, \mathrm{s}), 6.98(4 \mathrm{H}, \mathrm{s}), 7.26(2 \mathrm{H}, \mathrm{s}), 7.42(6 \mathrm{H}, \mathrm{m})$, $7.86(2 \mathrm{H}, \mathrm{m}), 8.63(2 \mathrm{H}, \mathrm{m})$. HRMS (ESI): calcd [M-H] ${ }^{-}$, 966.9705; found, 966.9705 .

\section{2-\{2,7-Dichloro-6-hydroxy-3-oxo-4,5-bis[(pyridin-2-ylmethylthiophen-2-ylmethylamino) methyl]-3H-xanthen-9-yl\}-3,4,5,6-tetrafluoro-benzoic Acid (7, Zinspy-F6, ZSF6)}

Portions of $\mathbf{1}(200 \mathrm{mg}, 0.971 \mathrm{mmol})$ and $\left(\mathrm{CH}_{2} \mathrm{O}\right)_{n}(48 \mathrm{mg}, 1.7 \mathrm{mmol})$ were combined in $5 \mathrm{~mL}$ of $\mathrm{MeCN}$ and heated to reflux for $1 \mathrm{~h}$. A slurry of 3,4,5,6-tetrafluoro-2',7'-dichlorofluorescein in $10 \mathrm{~mL}$ of $1: 1 \mathrm{MeCN} / \mathrm{H}_{2} \mathrm{O}$ was added to the reaction, and the solution turned dark pink. The reaction was refluxed for $22 \mathrm{~h}$, and a pink precipitate formed. The mixture was filtered, and the pink precipitate was washed with $10 \mathrm{~mL}$ of $\mathrm{H}_{2} \mathrm{O}$ and recrystallized twice from boiling EtOH (208 mg, 68\%); mp > $250{ }^{\circ} \mathrm{C}$, dec. ${ }^{1} \mathrm{H}$ NMR (DMSO- $\left.d_{6}, 300 \mathrm{MHz}\right): \delta 3.94(8 \mathrm{H}, \mathrm{s}), 4.04(4 \mathrm{H}$, s), $6.95(4 \mathrm{H}, \mathrm{m}), 7.23(2 \mathrm{H}, \mathrm{s}), 7.41(6 \mathrm{H}, \mathrm{m}), 7.83(2 \mathrm{H}, \mathrm{t}), 8.59$ (2H, d). HRMS (ESI): calcd $[\mathrm{M}-\mathrm{H}]^{-}, 903.0887$; found, 903.0893. Colorless block crystals suitable for X-ray crystallography were grown at room temperature by vapor diffusion of $\mathrm{Et}_{2} \mathrm{O}$ into a solution of ZSF6 in $\mathrm{H}_{2} \mathrm{Cl}_{2}$. 


\section{2-\{2,7-Difluoro-6-hydroxy-3-oxo-4,5-bis[(pyridin-2-ylmethylthiophen-2-yImethylamino) methyl]-3H-xanthen-9-yl\}-3,4,5,6-tetrafluoro-benzoic Acid (8, Zinspy-F7, ZSF7)}

Portions of $1(207 \mathrm{mg}, 1.01 \mathrm{mmol})$ and $\left(\mathrm{CH}_{2} \mathrm{O}\right)_{n}(50 \mathrm{mg}, 1.7 \mathrm{mmol})$ were combined in $6 \mathrm{~mL}$ of $\mathrm{MeCN}$ and heated to reflux for $30 \mathrm{~min}$. A slurry of 2',3,4,5,6,7'-hexafluoro-fluorescein (148 $\mathrm{mg}, 0.336 \mathrm{mmol}$ ) in $10 \mathrm{~mL}$ of $1: 1 \mathrm{MeCN} / \mathrm{H}_{2} \mathrm{O}$ was added to the reaction, and the solution turned deep pink-red. The reaction was heated to reflux for $24 \mathrm{~h}$ (during which time a pink precipitate formed), cooled, and filtered. The precipitate was recrystallized twice from boiling $\mathrm{EtOH}$, which gave the product as a pink-orange powder $(185 \mathrm{mg}, 63 \%) ; \mathrm{mp}>250{ }^{\circ} \mathrm{C}$, dec. ${ }^{1} \mathrm{H}$ NMR (DMSO- $d_{6}$ with NaOD, $\left.300 \mathrm{MHz}\right): \delta 3.78(4 \mathrm{H}, \mathrm{s}), 3.93(8 \mathrm{H}, \mathrm{s}), 6.66(2 \mathrm{H}, \mathrm{m})$, $6.89(4 \mathrm{H}, \mathrm{m}), 7.14(2 \mathrm{H}, \mathrm{m}), 7.33(2 \mathrm{H}, \mathrm{d}), 7.51(2 \mathrm{H}, \mathrm{m}), 7.61(2 \mathrm{H}, \mathrm{m}), 8.37(2 \mathrm{H}, \mathrm{m})$. HRMS (ESI): calcd [M-H] $]^{-}, 871.1478$; found, 871.1492.

\section{X-ray Crystallographic Studies}

Single crystals were mounted on the tips of glass fibers coated with paratone-N oil and cooled to $-100{ }^{\circ} \mathrm{C}$ under a stream of $\mathrm{N}_{2}$, maintained by a KRYO-FLEX low-temperature apparatus. Intensity data were collected on a Bruker APEX CCD diffractometer with graphitemonochromated Mo K $\alpha$ radiation $(\lambda=0.71073 \AA$ ), controlled by a Pentium-based PC running the SMART software package. ${ }^{67}$ Data collection and reduction protocols are described elsewhere. ${ }^{68}$ Empirical absorption corrections were applied by using the SADABS 69 program, and the structures were solved by direct methods using the SAINTPLUS ${ }^{70}$ and SHELXTL ${ }^{71}$ software packages. The structures were checked for higher symmetry by using the PLATON software. ${ }^{72}$ All non-hydrogen atoms were located and their positions refined with anisotropic thermal parameters by least-squares cycles and Fourier syntheses. Unless otherwise noted, hydrogen atoms were assigned to idealized positions and given thermal parameters equivalent to either 1.5 (methyl hydrogen atoms) or 1.2 (all other hydrogen atoms) times the thermal parameter of the carbon atom to which they were attached.

The structure of ZSF6 contains a dichloromethane molecule that was modeled as disordered over four positions (10:50:15:25). The sulfur and $\mathrm{C} 3$ carbon atoms of each thiophene group were modeled as disordered over two positions (50:50). The angles and the 1-2 distances around the sulfur and $\mathrm{C} 3$ carbon atoms were constrained to be the same for both components of the disordered thiophene rings. The $\mathrm{O} 1$ and $\mathrm{O} 3$ hydrogen atoms were located from the electron density map.

\section{General Spectroscopic Methods}

Aqueous solutions were prepared with Millipore water. Puratonic grade $\mathrm{KCl}$ was purchased from Calbiochem and molecular biology grade piperazine- $N, N^{\prime}$-bis(2-ethane-sulfonic acid) (PIPES) from Sigma. With the exception of the $\mathrm{p} K_{\mathrm{a}}$ titrations, measurements were generally made at $\mathrm{pH} 7$ in $50 \mathrm{mM}$ PIPES, $100 \mathrm{mM} \mathrm{KCl}$ buffer. A buffer containing $50 \mathrm{mM}$ CHES, 100 $\mathrm{mM} \mathrm{KCl}$ was employed for measurements at $\mathrm{pH}$ 9. Parallel experiments in buffer, rigorously treated or not treated with Chelex resin (Bio-Rad, manufacturer protocol) to remove any potentially adventitious metal ions, returned the same dynamic range and $K_{\mathrm{d}}$ values during trials that employed ZS5 or ZS7. Untreated buffer was used for all subsequent experiments. Excess EDTA was added to solutions of apo-ZS prior to quantum yield and extinction coefficient determinations. Zinc stock solutions $(100 \mathrm{mM}, 500 \mathrm{mM})$ were prepared from anhydrous $99.999 \% \mathrm{ZnCl}_{2}$ (Aldrich) and water. DMSO stock solutions (1 mM) of ZS sensors were prepared, partitioned into $\sim 300-\mu \mathrm{L}$ aliquots, stored at 4 or $-25^{\circ} \mathrm{C}$, and thawed in the dark before use. A starting solution of $10 \mathrm{mM} \mathrm{KOH}, 100 \mathrm{mM} \mathrm{KCl}, \mathrm{pH} \sim 12$, was used for $\mathrm{p} K_{\mathrm{a}}$ titrations, and the $\mathrm{pH}$ value of the solution was lowered by addition of $6,2,1,0.5$, or $0.1 \mathrm{~N}$ $\mathrm{HCl}$. Quantum yields were measured by using fluorescein in $0.1 \mathrm{~N} \mathrm{NaOH}(\Phi=0.95)$ as the standard, ${ }^{73}$ as described previously. ${ }^{47}$ Excitation was provided at 490 (Zn(II)-bound ZS5 and ZS7), 492 (apo-ZS5), 496 (apo-ZS7 and Zn(II)-bound ZS6), 499 (apo-ZS6), 500 (Zn(II)-bound 
ZSF7), 503 (apo-ZSF7), 504 (Zn(II)-bound ZSF6), or $505 \mathrm{~nm}$ (apo-ZSF6). Extinction coefficients were generally measured over a concentration range of $1-10 \mu \mathrm{M}$ for the metalfree and Zn(II)-bound species. Apo-ZS5 was an exception, which gives an uncharacteristically low $\left(\sim 12000 \mathrm{M}^{-1} \mathrm{~cm}^{-1}\right)$ extinction coefficient for symmetrical fluorescein-based sensors such as $Z \mathrm{PP}{ }^{47}$ and $\mathrm{QZ2}{ }^{50}$ in the $3-10 \mu \mathrm{M}$ range under these experimental conditions. Its extinction coefficient was therefore determined over a concentration range of $0-3 \mu \mathrm{M}$, which returned an expected value ( $>30000 \mathrm{M}^{-1} \mathrm{~cm}^{-1}$ ). For $\mathrm{Zn}$ (II) selectivity experiments, $\mathrm{ZP} 1^{47}$ was used as a control for the $\mathrm{Fe}(\mathrm{II}) / \mathrm{Zn}$ (II) studies. Sensors ZS6 and ZSCl6 were not (ZSCl6) or only partially (ZS6) characterized. These probes both suffer from low solubility in most solvents, including DMSO, and poor dynamic range ( 2-fold or less), and thus show little promise for biological imaging applications. Experimental details for all spectroscopic measurements performed in this study are available in the literature. ${ }^{47,74}$ All spectroscopic measurements were repeated a minimum of three times using material from at least two separate synthetic preparations, and the resulting averages are reported.

Fluorescence spectra were recorded on a Hitachi F-3010 spectrofluorimeter and UV-vis spectra on a Cary IE scanning spectrophotometer, both controlled by manufacturer-supplied software packages. Circulating water baths were used during all acquisitions to maintain the temperature at $25 \pm 1{ }^{\circ} \mathrm{C}$. Quartz cells (Starna) with a 1-cm path length were used for all measurements.

\section{Dissociation Constant Determination}

The apparent zinc complex dissociation constants for select ZS probes were determined by fluorimetric analysis. In a typical experiment, a $1 \mu \mathrm{M}$ solution of the $\mathrm{ZS}$ compound was prepared (50 mM PIPES, $100 \mathrm{mM} \mathrm{KCl}, \mathrm{pH} 7$ ) and its emission spectrum recorded. Various aliquots of 1 or $10 \mathrm{mM}$ aqueous $\mathrm{ZnCl}_{2}$ solutions were added, and the emission change was noted. The data were integrated, normalized with respect to the full response, and plotted against the total concentration of $\mathrm{Zn}$ (II) in solution. The data were fit to a 1:1 metal-ligand binding model. 75

\section{Stopped-Flow Kinetic Studies}

Single-mixing stopped-flow kinetics studies were performed with a Hi-Tech SF-61 DX2 double-mixing stopped-flow apparatus equipped with a fluorescence detector. Excitation was provided at 490 (ZS5, ZS7), 505 (ZS6), 510 (ZSF7), or $520 \mathrm{~nm}$ (ZSF6). A GG495 glass cutoff filter $(<455 \mathrm{~nm})$ was placed over the exit of the photomultiplier tube, and the emission was monitored from 455 to $700 \mathrm{~nm}$. All solutions were prepared in $50 \mathrm{mM}$ PIPES, $100 \mathrm{mM} \mathrm{KCl}$, pH 7 buffer. Conditions for pseudo-first-order kinetics were maintained by using at least a 10fold excess of $\mathrm{Zn}$ (II) in all experiments. Except for temperature-dependent studies, all experiments were conducted at $4.3 \pm 0.1^{\circ} \mathrm{C}$. The temperature inside the sample chamber was monitored with an internal thermocouple. A series of control experiments were conducted in which the initial ZS concentration was varied from 0.5 to $5 \mu \mathrm{M}$ after mixing to ensure that the observed rate constant was independent of initial dye concentration (data not shown). Multiple shots were taken for each Zn(II) (or sensor) concentration and averaged. Experiments were conducted three times with fresh Zn(II), sensor, and buffer solutions, and the resulting averages and standard deviations are reported. Observed rate constants were obtained by fitting individual traces to monoexponentials. The Kinet-Assyst software package (HiTech) was used to analyze the data. Further experimental details are available elsewhere. 50

\section{Cell Culture}

HeLa, COS-7, and HEK293-T cells were cultured in Dulbecco's Modified Eagle Medium (DMEM, Invitrogen) supplemented with 10\% fetal calf serum (FCS, Invitrogen), glutamine $(2 \mathrm{mM})$, penicillin (100 units $/ \mathrm{mL})$, and streptomycin $(100 \mu \mathrm{g} / \mathrm{mL})$. Two days before imaging, 
the cells were passed and plated on untreated (HeLa, COS-7) 10-mm glass coverslips or on glass coverslips coated with $0.2 \%$ gelatin for at least $1 \mathrm{~h}$ at room temperature (HEK293-T). For labeling, the growth medium was removed and replaced with DMEM containing 1\% FCS. The cells were treated and incubated with $10 \mu \mathrm{M}$ sensor at $37^{\circ} \mathrm{C}$ under $5 \% \mathrm{CO}_{2}$ for $30 \mathrm{~min}$. The cells were washed once with and bathed in DMEM containing no FCS prior to imaging and/or zinc addition. Zinc was introduced to the cultured cells as the pyrithione salt using a $\mathrm{Zn}$ (II)/pyrithione ratio of $1: 1$ or $1: 2$. Stock solutions of $\mathrm{ZnCl}_{2}(10 \mathrm{mM})$ and sodium pyrithione $(20 \mathrm{mM})$ in DMSO were combined and diluted 10-fold with DMEM prior to addition. In a typical experiment, a $100-\mu \mathrm{L}$ aliquot of this solution was added to the cells bathed in $2 \mathrm{~mL}$ of DMEM. A stock solution of TPEN (10 or $20 \mathrm{mM}$ ) was also diluted 10-fold with DMEM containing no FCS prior to cell treatment. $S$-Nitrosocysteine (SNOC, $10 \mathrm{mM}$ ) was prepared immediately before use according to a literature procedure. ${ }^{76}$

Lysotracker Red (Invitrogen) and Mitotracker Red (Invitrogen) were employed for colocalization studies. In a typical experiment, a $1 \mathrm{mM}$ solution of either marker in DMSO was diluted 100- to 200-fold with DMEM prior to cell treatment. The exact concentration of Lysotracker or Mitotracker used varied with lot number and was in the range of 100-500 nM. The cells were co-treated with the organelle marker and ZS5 or ZP3 and were generally incubated with the reagents for $30 \mathrm{~min}\left(37^{\circ} \mathrm{C}, 5 \% \mathrm{CO}_{2}\right)$ before imaging.

A pGolgi-DsRed construct was employed to label the Golgi apparatus. This plasmid expresses a fusion protein consisting of DsRed and a sequence encoding the $\mathrm{N}$-terminal 81 amino acids of human $\beta$-1,4-galactosyltransferase (Clonetech). The latter sequence includes a membraneanchoring signal peptide, which directs the fusion protein to the trans-Golgi region.

Overexpression of pGolgi-DsRed results in its presence in other compartments of the secretory pathway. HeLa cells were passed and plated onto untreated $10-\mathrm{mm}$ glass coverslips $36 \mathrm{~h}$ before transfection. The cells were transiently transfected with pGolgi-DsRed using the Lipofectamine reagent (manufacturer protocol) $24-36 \mathrm{~h}$ prior to imaging.

\section{Preparation of Embryonic Hippocampal Neuronal Cultures}

Hippocampal primary cultures were prepared from day 19 (E19) Sprague-Dawley rat embryos according to a previously reported protocol. ${ }^{77}$ Medium-density cultures $\left(150\right.$ cells $\left./ \mathrm{mm}^{2}\right)$ were plated on 24-mm glass coverslips coated with poly-D-lysine $(30 \mu \mathrm{g} / \mathrm{mL})$ and laminin $(2.5 \mu \mathrm{g} /$ $\mathrm{mL}$ ). Hippocampal cultures were grown in Neurobasal media (Invitrogen) supplemented with B27 (Invitrogen), glutamine $(0.5 \mathrm{mM})$, and glutamate $(12.5 \mu \mathrm{M})$. After 16-20 days in culture, the medium was removed and replaced with fresh Neurobasal containing no B27. The cells were stained by bath application of the appropriate dye to the media and incubated at $37^{\circ} \mathrm{C}$ under 5\% $\mathrm{CO}_{2}$. The ZS5 stock solution (1 mM in DMSO) was diluted 10-fold with either Neurobasal or PBS before addition. The Zn(II)/pyrithione mix has poor solubility in Neurobasal, so these DMSO stock solutions were diluted with either PBS or serum-free DMEM before addition. In some instances, the neurons were transfected with $3.6 \mu \mathrm{g}$ of $\beta$-actin dsRed DNA using Lipofectamine 2000 (manufacturer protocol). The neurons were incubated with the DNA/lipofectamine mix for $1 \mathrm{~h}\left(37^{\circ} \mathrm{C}, 5 \% \mathrm{CO}_{2}\right)$ on DIV 16 , washed with and bathed in the growth medium, and imaged on DIV 19 or 20. Solutions of $\mathrm{Zn}$ (II)/glutamate (1:2 Zn(II)/ glutamate ratio) were prepared in PBS from aqueous solutions of $\mathrm{ZnCl}_{2}(10 \mathrm{mM})$ and glutamate $(10 \mathrm{mM})$ and used immediately. Experiments were conducted in a minimum of four independently prepared cultures.

\section{Preparation of Postnatal Dentate Gyrus Neuronal Cultures}

Primary cultures of dentate gyrus (DG) cells were prepared by modification of a literature procedure. ${ }^{78}$ DG regions were dissected from the hippocampi of 4-day-old Sprague Dawley rat pups. The cells were plated on $24-\mathrm{mm}$ glass coverslips $\left(250 \mathrm{cells} / \mathrm{mm}^{3}\right)$ coated with poly- 
L-lysine (Sigma, $50 \mu \mathrm{g} / \mathrm{mL}$ ). The cultures were maintained for the first $24 \mathrm{~h}$ in DMEM (Invitrogen) supplemented with 10\% FCS (Invitrogen), glutamine (2 mM), and penicillinstreptomycin mix $(50 \mu \mathrm{g} / \mathrm{mL})$. Subsequently, the cells were kept in Neurobasal medium (Invitrogen) supplemented with B27 (Invitrogen), glutamine ( $2 \mathrm{mM})$, potassium chloride (20 $\mathrm{mM})$, and penicillin-streptomycin mix $(50 \mu \mathrm{g} / \mathrm{mL})$. After 7 days in culture, the medium was removed and replaced with Neurobasal containing no B27, and the cells were treated with ZS5 and $\mathrm{Zn}(\mathrm{II}) /$ pyrithione as described above for the hippocampal neurons. For experiments requiring SNOC, the reagent was prepared immediately before use and added to the cells by application on the microscope stage. Experiments were conducted with two independently prepared cultures.

\section{Cytotoxicity Assays in HeLa Cells}

To ascertain the cytotoxic effect of sensor treatment over a 24-h period, HeLa cells were passed and plated to $\sim 60 \%$ confluence in 12-well plates $12-16 \mathrm{~h}$ before treatment and bathed in $1 \mathrm{~mL}$ of DMEM supplemented as described above. Prior to ZP treatment, the DMEM was removed and replaced with fresh DMEM, and aliquots of ZP1, ${ }^{47} \mathrm{ZP} 3,{ }^{49}$ or ZS5 stock solutions (1 mM DMSO) were added for final concentrations of 1,5 , and $10 \mu \mathrm{M}$. The treated cells were incubated for $24 \mathrm{~h}$ at $37{ }^{\circ} \mathrm{C}$ and under $5 \% \mathrm{CO}_{2}$. Subsequently, the cells were treated with $5 \mathrm{mg} / \mathrm{mL}$ MTT $(100 \mu \mathrm{L} /$ well $)$ and incubated for an additional $2-4 \mathrm{~h}\left(37^{\circ} \mathrm{C}, 5 \% \mathrm{CO}_{2}\right)$. The DMEM was removed, the cells were dissolved in DMSO $(500 \mu \mathrm{L} /$ well $)$, and the absorbance at $550 \mathrm{~nm}$ was recorded. Three independent trials were conducted, and the averages and standard deviations are reported. The reported percent cell survival values are relative to untreated control cells. Additional control studies indicated that the DMSO added (1-10 $\mu \mathrm{L})$ as a result of sensor treatment has no effect on cell viability under these conditions. The HeLa cells used were at P-10 to P-16, and the assays were repeated using a minimum of two separate HeLa cell stocks.

\section{Laser Scanning Confocal Microscopy}

A Zeiss LSM510 microscope equipped with a $63 \times$ or $100 \times$ oil-immersion objective was used to obtain confocal images. For co-localization experiments, electronic zoom $(1.5 \times)$ was used in combination with the $100 \times$ objective. Samples were excited at $488 \mathrm{~nm}$ with an Ar laser. The microscope stage was outfitted with a CTI-3700 incubator, which maintained samples at $37^{\circ}$ $\mathrm{C}$ and under $5 \% \mathrm{CO}_{2}$. With the exception of ZS5 treatment, which was performed in a tissue culture hood, addition of all reagents was carried out by bath application on the microscope stage.

\section{Results and Discussion \\ Design and Syntheses of Probes}

Two main considerations influenced the design of the sensors described in this work. Our primary goal was to improve the dynamic range and maintain both the $\mathrm{Zn}(\mathrm{II})$ selectivity and relatively low $\mathrm{Zn}$ (II) affinity of thioether-containing ZS sensors. We therefore substituted the thioether moiety of our first-generation ZS sensors with a thiophene group. We anticipated that replacement of an alkyl chain with an aromatic heterocycle would result in lower background emission and, in turn, greater fluorescence enhancement following $\mathrm{Zn}$ (II) coordination. A second objective was to prepare sensors in relatively few steps and high yield. For this reason, we focus on symmetrical species with tertiary-amine-based ligands, which can generally be obtained in six or fewer steps from commercially available materials.

Scheme 1 illustrates the syntheses of symmetrical ZS sensors $\mathbf{3}-\mathbf{8}$ from fluorescein precursors. Probes containing halogenated fluorophores were prepared by Mannich reactions of the fluorescein and the imminium ion condensation product of paraformaldehyde and $\mathbf{1}$. In each case, the desired product precipitated from the reaction solution, and multiple (two or three) 
recrystallizations of the precipitates from boiling EtOH yielded sensors 4-8 as light to bright pink powders in moderate to high yields. Fluorescein-based ZS5 (3) was prepared from 1 and dialdehyde 2 (Scheme 1) using $\mathrm{NaB}(\mathrm{OAc})_{3} \mathrm{H}$ as the reducing agent and obtained in moderate yield after workup and preparative TLC on silica gel

There are few reported crystal structures of fluorescein-based compounds. This paucity most likely stems from the fact that fluoresceins can adopt many isomers, including quinoid and lactone forms, which makes crystallization difficult. Since we could easily prepare relatively large (often $>100 \mathrm{mg}$ ) quantities of the ZS sensors described in this work, we were able, through multiple attempts, to obtain X-ray-quality crystals of a ZS sensor. Single crystals of ZSF6 were obtained by vapor diffusion of $\mathrm{Et}_{2} \mathrm{O}$ into a solution of the sensor in $\mathrm{CH}_{2} \mathrm{Cl}_{2}$ at room temperature. Figure 2 displays the ORTEP diagram of ZSF6, and Tables S1 and S2 (Supporting Information) provide crystallographic parameters and selected bond lengths and angles, respectively. ZSF6 crystallized in the lactone form, affording a colorless and non-fluorescent material, as previously observed for the dinuclear ZP1:Zn(II) complex ${ }^{47}$ and ZPCl1. ${ }^{79}$ The hydrogen atoms of $\mathrm{O} 1$ and $\mathrm{O} 3$ were located from a difference electron density map, and both form hydrogen bonds with the nitrogen atoms of the pyridyl-amine-thiophene moieties. The $\mathrm{O} 1$ proton is hydrogen-bonded to both the tertiary amine N1 and pyridyl N2 atoms, with O1-N1 and O1-N2 distances of 3.190(3) and 2.599(3) ̊, respectively. The O3 proton is hydrogenbonded to the tertiary amine N3 atom, with an O3-N3 distance of 2.634(3) $\AA$. No hydrogenbonding interactions are observed with the thiophene moieties, as expected given the poor basicity of this group.

\section{Photophysical Properties of Thiophene-Containing ZS Sensors}

Table 1 summarizes photophysical characterization and thermodynamic parameters for ZS sensors, in addition to data for the symmetrical ZP probes for comparison. In general, halogenation of the fluorescein platform induces red-shifts in both excitation and emission maxima. Chlorination or fluorination of the benzoate rings causes ca. $20 \mathrm{~nm}$ red-shifts, and chlorination of the $2^{\prime}$ and $7^{\prime}$ positions of the xanthenone framework also results in red-shifts relative to fluorescein and its $2^{\prime}, 7^{\prime}$-difluoro derivative. These substitutions afford an excitation and emission range of $\sim 35 \mathrm{~nm}$, similar to that of the halogenated ZP family. ${ }^{49}$ Although modest, this feature could be useful for biological imaging experiments that require two $\mathrm{Zn}$ (II)-specific probes or for dual $\mathrm{Zn}$ (II) and $\mathrm{Ca}$ (II) sensing.

Introduction of a thiophene group into the metal-binding unit results in lower background emission and greater fluorescence enhancement than observed for thioether-containing ZS1 and ZS2. This trend is particularly evident for the ZS2/ZS7 pair, where $\Phi_{\text {free }}$ decreases from 0.39 to 0.25 (50 mM PIPES, $100 \mathrm{mM} \mathrm{KCl}, \mathrm{pH} 7)$. As a result, the quantum yields and dynamic ranges of thiophene-containing ZS more closely resemble those of the ZP family, although $\Phi_{\text {free }}$ is consistently higher and indicates that DPA quenches the fluorescein excited state more effectively than the pyridyl-amine-thiophene moiety. Depending on the substitution pattern on the fluorescein rings, compounds 3-8 offer $\sim 2$ - (ZS6, ZSCl6) to >4.5-fold (ZSF7)

fluorescence turn-on following $\mathrm{Zn}$ (II) coordination. Representative emission spectra are given in Figures 3 and S1-S3 (Supporting Information). The optical absorption spectra of both $\mathrm{Zn}$ (II)-free and -bound forms of the ZS sensors are characterized by high molar extinction coefficients, and $\mathrm{Zn}$ (II) coordination results in a slight (ca. $10 \mathrm{~nm}$ ) blue-shift and increase in the molar absorptivity. This behavior parallels that of many previously characterized ZS and $\mathrm{ZP}$ sensors and indicates that the phenol moiety is involved in $\mathrm{Zn}$ (II) coordination.

The data in Table 1 reveal that substitution of the $2^{\prime}$ and $7^{\prime}$ positions of the xanthenone moiety causes systematic variations in $\Phi_{\text {free }}$ that are independent of ligand type. For both ZP and ZS, the magnitude of $\Phi_{\text {free }}$ decreases as $\mathrm{X}=\mathrm{Cl}>\mathrm{H}>\mathrm{F}$. Similar background fluorescence reduction has been observed by others upon substitution of fluorescein with $2^{\prime}, 7^{\prime}$-difluoro-fluorescein. 
43 Although the origin of this effect is unclear, it is generally applicable to the design of fluorescein-based metal ion sensors.

The ZS sensors presented in this study operate via a PET mechanism. ${ }^{80}$ Sensors of this type are often $\mathrm{pH}$-sensitive. Figure 4 displays representative $\mathrm{pH}$ titrations for selected probes, and $\mathrm{p} K_{\mathrm{a}}$ values are given in Table 1. We first consider ZS5-7, which lack benzoate ring halogenation (Figure 4, top). Like ZP1-3, the 2', 7'-dichloro (ZS6) and 2',7'-difluoro platforms (ZS7) shift the $\mathrm{pH}$ titration curve toward lower values relative to that of the unsubstituted fluroescein (ZS5). This trend parallels the known $\mathrm{pH}$-dependent emission profiles and $\mathrm{p} K_{\mathrm{a}}$ values of the parent fluorophores, with fluorescein having a phenolic $\mathrm{p} K_{\mathrm{a}}$ value of $6.4,81$ compared to $5.0^{82}$ for $2^{\prime}, 7^{\prime}$-dichloro- and $4.8^{83}$ for $2^{\prime}, 7^{\prime}$-difluorofluorescein. As a result, the $\mathrm{p} K_{\mathrm{a}}$ transition assigned to tertiary amine protonation decreases from $8.0(\mathrm{ZS} 5, \mathrm{X}=\mathrm{H})$ to 7.0 (ZS7, $\mathrm{X}=\mathrm{F}$ ). Fluorescence quenching occurs at $\mathrm{pH}<\sim 6$ when the phenol group becomes protonated. These $\mathrm{p} K_{\mathrm{a}}$ values range from 4.6 to 2.7 with $\mathrm{X}=\mathrm{H}>\mathrm{Cl} \sim \mathrm{F}$.

Titrations of bottom-ring-halogenated ZSF6 and ZSF7 are given in the bottom panel of Figure 4. These profiles are both characterized by two $\mathrm{p} K_{\mathrm{a}}$ transitions, with $\mathrm{p} K_{\mathrm{a} 1} \approx 7$ assigned to tertiary amine protonation and $\mathrm{p} K_{\mathrm{a} 2}<3$ assigned to protonation of the phenol. The $\mathrm{p} K_{\mathrm{a} 1}$ values are similar to those observed for $\mathrm{ZPF} 1\left(\mathrm{p} K_{\mathrm{a}}=6.9\right)$ and $\mathrm{ZPF} 3\left(\mathrm{p} K_{\mathrm{a}}=6.7\right)$ and follow the same trend of further diminution upon fluorination of the $2^{\prime}$ and 7 ' positions. Scheme $S 1$ depicts the protonation equibria for the thiophene-containing ZS sensors proposed on the basis of these experiments and on the low basicity of thiophene moieties.

The titrations in Figure 4 illustrate that emission of the ZS sensors is effectively quenched at high $\mathrm{pH}$. The quantum yield of apo-ZS5 drops from 0.36 at $\mathrm{pH} 7$ to 0.04 at $\mathrm{pH} 9$. As a result, ZS5 shows $>20$-fold fluorescence enhancement following $\mathrm{Zn}$ (II) coordination at $\mathrm{pH}$ 9, with $\Phi_{\mathrm{Zn}}=0.73(50 \mathrm{mM}$ CHES, $100 \mathrm{mM} \mathrm{KCl}$ ), as compared to $\sim$-fold enhancement at $\mathrm{pH} 7$ (50 $\mathrm{mM}$ PIPES, $100 \mathrm{mM} \mathrm{KCl})$. This behavior is consistent with the PET mechanism.

\section{Metal-Binding Properties. I. Zinc Affinity and Coordination}

Fluorescence spectroscopy was used to determine apparent $\mathrm{Zn}$ (II) complex $K_{\mathrm{d}}$ values for ZS5, ZSF6, ZS7, and ZSF7, which are listed in Table 2. Representative binding curves are given in Figure 3 (ZS5) and as Supporting Information (ZSF6, ZS7, ZSF7). Fluorescein-based ZS5 exhibits maximum fluorescence in the presence of $\sim 10$ equiv of $\mathrm{Zn}(\mathrm{II})$ and has a $K_{\mathrm{d}}$ value of $1.5 \pm 0.2 \mu \mathrm{M}$. This value is $\sim 3$ orders of magnitude greater than the $K_{\mathrm{d} 1}$ value of $\mathrm{ZP} 2\left(K_{\mathrm{d} 1}=\right.$ $0.5 \pm 0.1 \mathrm{nM})^{47}$ and about twice that of asymmetrical ZP9 $\left(K_{\mathrm{d}}=0.69 \pm 0.04 \mu \mathrm{M}\right) .{ }^{84}$

Halogenation of the xanthenone and benzoate moieties raises the $K_{\mathrm{d}}$ significantly, with values for ZS7, ZSF6, and ZSF7 of $3.7 \pm 0.4,4.6 \pm 0.2$, and $5.0 \pm 0.3 \mu \mathrm{M}$, respectively. We attribute this behavior to variation in the donor ability of the deprotonated phenol group. Incorporation of halogens reduces the electron density on the oxygen atom, making it a poor donor relative to $\mathrm{X}=\mathrm{H}$. As a result, the $\mathrm{Zn}-\mathrm{O}$ bond is weaker in chlorinated and fluorinated $\mathrm{ZS}$ relative to ZS5. This trend is in accord with the $\mathrm{pH}$ studies on fluorescein and its halogenated derivatives, where the $\mathrm{p} K_{\mathrm{a}}$ of the phenol decreases with chlorination and fluorination of the fluorescein platform, respectively. ${ }^{82,83}$ This behavior is somewhat evident in the $K_{\mathrm{d}}$ values for the symmetrical ZP probes, which range from 0.5 to $1.1 \mathrm{nM}^{49}$

Thiophenes are weak bases with low affinity for many divalent metal ions, including $\mathrm{Zn}(\mathrm{II})$. To establish that the thiophene moiety is not involved in $\mathrm{Zn}$ (II) coordination, X-ray crystallographic studies were conducted using a salicylaldehyde-based model of ZS5. A report of this study is given as Supporting Information. Single crystals were obtained from smallscale crystallization trials, and X-ray structural determination of these complexes confirmed 
that the thiophene moiety of the model ligand does not bind to $\mathrm{Zn}$ (II) or to other divalent firstrow transition metal ions, including $\mathrm{Cu}$ (II) (Figure S4).

Sensors 3-8 have two possible metal-binding sites. By analogy to the symmetrical ZP systems and from chemical intuition, we propose stepwise binding with formation of the 1:1 ZS:Zn(II) complexes at relatively low $\mathrm{Zn}(\mathrm{II})$ concentrations and formation of 1:2 complexes at significantly higher concentrations of $\mathrm{Zn}(\mathrm{II})$. Fluorimetric titrations show that the fluorescence response of $1 \mu \mathrm{M} \mathrm{ZS}$ to $\mathrm{Zn}$ (II) maximizes at 10-50 $\mu \mathrm{M} \mathrm{Zn}$ (II), depending on the fluorophore platform, which indicates that the second binding event has little influence on the fluorescence response. For this reason, values for $K_{\mathrm{d} 2}$ were not determined.

\section{Zinc Selectivity}

One objective of this investigation was to maintain the Zn(II) selectivity observed for thioethercontaining ZS. Figure 5 illustrates the selectivity of ZS5 for Zn(II) in the presence of biologically relevant cations, divalent first-row transition metal ions, $\mathrm{Cd}$ (II) and $\mathrm{Hg}$ (II). The data for the halogenated sensors are generally analogous, although the degree of quenching observed following $\mathrm{Hg}$ (II) addition varies with fluorescein halogenation. As anticipated, the behavior of ZS5 follows that of ZS1-4, maintaining the selectivity for Zn(II) over Fe(II). The greater affinity of ZS5 for $\mathrm{Zn}(\mathrm{II})$ vs $\mathrm{Hg}$ (II) is an improvement over the thioether-containing ZS sensors because Zn(II) addition to solutions of ZS1-4 and $\mathrm{Hg}$ (II) does not cause any fluorescence change. ${ }^{64}$ This difference results from loss of a strong $\mathrm{Hg}-\mathrm{S}$ bond between the metal ion center and the thioether donor.

\section{Kinetics and Thermodynamics of $\mathrm{Zn}$ (II) Association}

The fluorescence responses of the ZS probes are observable immediately after Zn(II) addition. We therefore conducted stopped-flow kinetic studies to determine the rate constants for $\mathrm{Zn}$ (II) association, measured by fluorescence turn-on, for these sensors. Table 2 lists the experimentally determined second-order rate constants for $\mathrm{Zn}(\mathrm{II})$ association $\left(k_{\mathrm{on}}\right)$ and, in most instances, calculated rate constants for $\mathrm{Zn}$ (II) dissociation $\left(k_{\mathrm{off}}\right)$. Plots of $k_{\mathrm{obs}}$ versus $\mathrm{Zn}$ (II) concentration are given in Figure 6, which return $k_{\text {on }}$ values ranging from $3.3 \times 10^{5}$ to $5.9 \times$ $10^{5} \mathrm{M}^{-1} \mathrm{~s}^{-1}$ at $4.3^{\circ} \mathrm{C}$. Data from temperature variation experiments indicate $k_{\text {on }}$ values of 1.8 $\times 10^{6}$ to $3.0 \times 10^{6} \mathrm{M}^{-1} \mathrm{~s}^{-1}$ at $25^{\circ} \mathrm{C}$, which are comparable to those of DPA-based probes such as $\mathrm{ZP}^{50}$ and $\mathrm{ZnAF}^{44}$ family members. The dissociation rate constants, $k_{\text {off }}$, were calculated from the experimentally determined $k_{\text {on }}$ and $K_{\mathrm{d}}$ values and range from 3.3 to $13.5 \mathrm{~s}^{-1}$ at $25^{\circ}$ $\mathrm{C}$, yielding $t_{1 / 2}$ values of 50-210 ms. These kinetic parameters demonstrate that the ZS sensors bind Zn(II) both rapidly and, significantly, more reversibly than DPA-based ZP. Furthermore, these data are in accord with rate constants obtained for ZnAF probes, which indicated that (i) one pyridyl group in a DPA-like chelate is sufficient for maintaining fast $\mathrm{Zn}$ (II) complexation and (ii) the rate of $\mathrm{Zn}$ (II) dissociation is significantly more sensitive to loss of a DPA pyridyl group. 44

Halogenation of the fluorescein platform has subtle effects on the $k_{\text {on }}$ values. Both the ZP1/ ZP3 and ZS6/ZS7 couples show that fluorination of the $2^{\prime}$ and 7' positions increases the magnitude of $k_{\text {on }}$ relative to chlorination. Comparison of the ZS couples ZS6/ZSF6 and ZS7/ ZSF7 indicates that fluorination of the benzoate moiety decreases $k_{\text {on }}$ to some degree.

Temperature variation experiments were conducted to determine the activation enthalpies and entropies for $\mathrm{Zn}$ (II) coordination to the ZS sensors, and these data are also included in Table 2. Figure $S 6$ displays representative Eyring plots for each probe, from which we compute $\Delta H^{\ddagger}$ to be $12.6-13.3 \mathrm{kcal} / \mathrm{mol}$ and $\Delta S^{\ddagger}$ to range from 12.4 to $15.2 \mathrm{cal} / \mathrm{mol} \cdot \mathrm{K}$. The former values are indicative of a low activation barrier and fast association rate; they are comparable to those determined for ZP family members. The positive $\Delta S^{\ddagger}$ values are also typical of fluorescein- 
based sensors designed in our laboratory, which we presume reflect loss of water molecules or buffer components from the $\mathrm{Zn}$ (II) center or loss of protons from ZS in the transition state during binding.

\section{Biological Imaging Studies. I. Response of ZS5 to Zinc in Cultured Cells and Subcellular Localization}

Several features of the ZS probes, including improved dynamic range relative to the thioethercontaining parent compounds and low-micro-molar affinity for Zn(II), motivated us to consider their utility for in vivo work. We began these investigations with ZS5, the first compound we prepared, and quickly found that it is amenable for such experiments. We therefore focused our attention on this probe for biological imaging.

Initial cell studies indicated that ZS5 permeates a number of commercially available immortal cell lines and is $\mathrm{Zn}$ (II)-responsive in vivo. Figure S7 exhibits representative images of ZS5treated HeLa, COS-7, and HEK293-T cells. In preliminary work, the cells were treated with $10 \mu \mathrm{M}$ ZS5 for varying incubation times, which reveal $30 \mathrm{~min}\left(37^{\circ} \mathrm{C}, 5 \% \mathrm{CO}_{2}\right)$ to be optimal. Longer incubation periods ( $>1 \mathrm{~h}$ ) are also acceptable, but shorter (ca. $20 \mathrm{~min}$ or less) ones result in insufficient sensor uptake. Addition of $\mathrm{Zn}$ (II) to the cells as the 1:1 or 1:2 Zn(II)/ pyrithione complex affords intracellular fluorescence enhancement, which is reversed with TPEN treatment (Figure S7).

An important observation from these preliminary experiments concerned the subcellular localization of ZS5 in HeLa cells. Figure 7 shows a side-by-side comparison of HeLa cells treated with $10 \mu \mathrm{M} \mathrm{ZS5}$ or ZP3 and $100 \mu \mathrm{M} \mathrm{Zn(II)/pyrithione.} \mathrm{ZP3} \mathrm{exhibits} \mathrm{punctate} \mathrm{staining,}$ similar to that previously reported for ZP1 in COS-7 cells, ${ }^{47}$ whereas the ZS5 pattern is much more diffuse. Co-localization studies were therefore conducted in HeLa cells to determine where ZS5 and ZP3 reside, and representative images are provided in Figures S8 and S9. Treatment of HeLa cells with ZS5 (free or zinc-bound) and either Lysotracker or pGolgi-DsRed showed that this dye does not localize to either the lysosomes or the Golgi apparatus. Excellent co-localization of ZS5 and Mitotracker Red was observed, which establishes that ZS5 is sequestered in the mitochondria of healthy HeLa cells. In contrast, ZP3 shows excellent colocalization with pGolgi-DsRed and no overlap with the Lysotracker and Mitotracker markers, which establishes Golgi compartmentalization of this probe in HeLa cells.

The observation that $\mathrm{Zn}$ (II) sensors can be directed to different subcellular organelles as a result of structural modification is intriguing and potentially advantageous. Although subcellular compartmentalization of sensors has been described as problematic in the calcium sensor literature, ${ }^{37}$ we believe that a clear understanding of sensor localization in the cell type under study will be beneficial for studying $\mathrm{Zn}$ (II) entry into and trafficking between certain organelles. Mitochondrial localization is relevant from the standpoint of $\mathrm{Zn}(\mathrm{II})$ toxicity, because rapid influx of $\mathrm{Zn}(\mathrm{II})$ into the mitochondria has been implicated in neuronal death. $28,31,85,86$

\section{Response of ZS5 to Zinc in Primary Neuronal Cultures}

We next focused our efforts on studying the behavior of ZS5 in primary neuronal cultures from pre- or postnatal rat. Two different types of neuronal cultures were used in this work. ${ }^{87}$ Figure 8 exhibits representative images of both embryonic hippocampal and postnatal dentate gyrus neurons treated with ZS5 and exogenous Zn(II). ZS5 enters and is Zn(II)-responsive and reversible in both cell types.

A series of time-course experiments, in which cells were treated with $10 \mu \mathrm{M}$ ZS5 and $50 \mu \mathrm{M}$ $\mathrm{Zn}(\mathrm{II}) /$ pyrithione and imaged over the course of 1-5 min, revealed that ZS5 responds to 
exogenously added $\mathrm{Zn}$ (II) more quickly in neurons than in other cell types, such as HeLa and COS-7. Whereas ca. 1 min of incubation was sufficient to observe full fluorescence enhancement in hippocampal neurons following treatment with $50 \mu \mathrm{M} \mathrm{Zn(II)/pyrithione,} \mathrm{ca.}$ 5 min was required to observe complete turn-on in HeLa cells. We believe that this variation stems from the relative ability of the HeLa cells and neurons to internalize the $\mathrm{Zn}(\mathrm{II}) /$ pyrithione complex. From a molecular standpoint, the difference in $\mathrm{Zn}$ (II)/pyrithione uptake might arise from the greater diversity of ligand, voltage, and resting cation membrane channels in neurons relative to HeLa cells.

We therefore questioned whether ZS5 would respond to $\mathrm{Zn}$ (II) on a faster time scale in vivo, a feature that is necessary for monitoring biological $\mathrm{Zn}$ (II) flux. Figure 9 shows time-series images of a hippocampal neuronal cell body treated with $10 \mu \mathrm{M}$ ZS5 before and after addition of $50 \mu \mathrm{M}$ 1:1 Zn(II)/pyrithione and $50 \mu \mathrm{M}$ TPEN. The images were captured at $\sim 2.4$-s intervals and show that ZS5 responds to $\mathrm{Zn}$ (II) on this time scale in living cells. We chose this time interval because it allowed for real-time visualization of the signal on the computer screen without any image manipulation. Control studies show that pretreatment of the neurons with TPEN blocks any response of ZS5 to Zn(II)/pyrithione (data not shown). The origin of the fluorescence rise that occurs in the ca. $4 \mathrm{~s}$ following TPEN addition is unclear to us, but it is reproducible, and we have also observed this phenomenon in HeLa cells. The value of these experiments lies in their proof that ZS5 can respond to and release Zn(II) rapidly in a biological system, which points toward its utility for monitoring $\mathrm{Zn}$ (II) flux.

\section{Effect of Glutamate on Exogenous Zinc Uptake}

Treating cells with $\mathrm{Zn}(\mathrm{II}) /$ pyrithione is essentially a brute force approach to generating a robust intracellular signal. Pyrithione appears to deliver Zn(II) indiscriminately throughout the cell. As a result, experiments that use $\mathrm{Zn}(\mathrm{II}) /$ pyrithione have little physiological or pathophysiological significance. We were therefore motivated to investigate other routes of $\mathrm{Zn}$ (II) entry that may be relevant to neurobiological signaling.

The Zn(II)-containing synaptic vesicles in the mammalian hippocampus also house glutamate (E), an excitatory neu-rotransmitter, and both species are released into the synaptic cleft following exocytosis of vesicles at the pre-synaptic membrane. Given this association, it is reasonable to think that glutamate may modulate $\mathrm{Zn}$ (II) uptake into the post-synaptic neuron or other nearby cells. Several reports indicate that glutamate or kainate, a glutamate mimic, can trigger excessive intracellular accumulation of $\mathrm{Zn}(\mathrm{II})$ in cortical neurons. ${ }^{86,88,89} \mathrm{We}$ therefore co-treated ZS5-loaded hippocampal neurons with $\mathrm{ZnCl}_{2}$ and glutamate (1:2 ratio, 50 $\mu \mathrm{M}$ zinc) and monitored the intracellular response by fluorescence microscopy. Figure 10 displays representative images, which show significantly different staining than that observed for neurons treated with $\mathrm{Zn}(\mathrm{II}) /$ pyrithione. Fluorescence enhancements occur in several neuronal projections $1 \mathrm{~min}$ after addition of the $\mathrm{Zn}(\mathrm{II}) / \mathrm{E} \mathrm{mix}$, and this rise persists for at least 5 min (Figure S11). The staining pattern consists of green dots that may be associated with dendritic spines and/or GABA synapses, although detailed co-localization studies must be conducted to address these possibilities. Control studies in which hippocampal neurons were treated with only $\mathrm{ZnCl}_{2}(50 \mu \mathrm{M})$ showed no fluorescence change over a 5-min time frame, indicating that $\mathrm{Zn}(\mathrm{II})$ alone does not permeate the neuronal cell membrane over this time period (Figure S11). Additional control studies, in which the ZS5-loaded neurons were treated with glutamate $(100 \mu \mathrm{M})$ for $5 \mathrm{~min}$, also showed no fluorescence change (Figure S11). This experiment illustrates that extracellular glutamate modulates the uptake of $\mathrm{Zn}$ (II) into hippocampal neurons rapidly and at specific locales. 


\section{Imaging Endogenous Zinc Mobilization with ZS5}

We previously demonstrated that ZNP1, a ratiometric Zn(II) indicator with a sub-nanomolar $K_{\mathrm{d}}$ value for this metal ion, can detect endogenous $\mathrm{Zn}(\mathrm{II})$ mobilization in cultured COS-7 cells following SNOC treatment. ${ }^{54}$ We therefore wondered whether ZS5 would illuminate $\mathrm{Zn}$ (II) mobilization in live cells following nitrosative stress. We chose neurons from the zinc-rich dentate gyrus region of the rat hippocampus for this experiment. Figure 11 shows a time-course experiment in which dentate gyrus neurons were loaded with $10 \mu \mathrm{M}$ ZS5 and subsequently treated with SNOC. Significant fluorescence enhancement occurs in the neuron cell bodies and projections, and in surrounding glial cells, at ca. 3 min following SNOC addition, and the response maximizes at ca. 5 min.

To confirm that the observed changes in ZS5 fluorescence intensity observed after SNOC treatment are due to the NO-induced release of $\mathrm{Zn}$ (II) from native protein stores rather than to general cell toxicity, we monitored neuronal cell viability $30 \mathrm{~min}$ after SNOC application by employing established protocols for assaying cell death in dentate gyrus neurons. ${ }^{78} \mathrm{In}$ particular, we analyzed nuclear and dendritic morphology using DAPI (nuclear stain) and MAP2 (dendritic marker), as described in the Supporting Information. No statistically significant difference was observed in a comparison of nuclear morphology in untreated control and SNOC-treated cells (control, 96.7\% survival; SNOC, 95.1\% survival), and dendritic fragmentation, characteristic of apoptotic DG neurons, was not observed (Figure S10). Together, these experiments establish that dentate gyrus neurons can release $\mathrm{Zn}$ (II) from native protein stores at concentrations observable with a low-micromolar affinity probe as a result of nitrosative stress.

\section{Probe Cytotoxicity}

Cytotoxicity is a potential side effect of a probe that must be controlled when dealing with living cells or tissues. Although we saw no evidence for cytotoxic effects during the experiments described in this work, these studies required relatively short time frames. We were therefore interested in studying the possible consequences of a more extended sensor treatment on cell viability. To date, we have conduced cytotoxicity assays only in HeLa cells, but this information should prove useful in the design of experiments requiring other cell lines. Table 3 lists the cell viability data for HeLa cells treated with ZP1, ZP3, and ZS5 as quantified by the MTT assay, an established method of probing apoptotic cell death. Corresponding bar graphs are given in Figure S12. These data show that HeLa cells show $\sim 100 \%$ viability following 24-h treatment with $1 \mu \mathrm{M}$ ZP1, ZP3, or ZS5. Higher sensor concentrations result in decreased cell survival, with $80 \%$ ( $\pm 4 \%$ viability observed following 24 -h treatment with 10 $\mu \mathrm{M}$ ZS5. These cytotoxicity tests indicate that sub- and low-micromolar concentrations of ZP and ZS5 are essentially nontoxic over at least a 24 -h period and can safely be used for biological studies that require prolonged sensor treatment.

\section{Summary}

Turn-on fluorescent $\mathrm{Zn}$ (II) sensors of the Zinspy family give improved dynamic range by substituting thioethers with thiophene groups, which affords lower background fluorescence and bright $\mathrm{Zn}$ (II) complexes. These sensors exhibit a number of advantageous features. From a chemical perspective, they provide (i) dissociation constants in the low micromolar range, (ii) fast $\mathrm{Zn}$ (II) association rates comparable to those observed for $\mathrm{Zn}$ (II) sensors employing the DPA chelate but with more rapid $\mathrm{Zn}$ (II) dissocation, and (iii) improved selectivity for $\mathrm{Zn}$ (II) compared to the parent ZP and ZS compounds. Our studies demonstrate that fluorescein halogenation is a general strategy for modulating not only photophysical but also metal-binding properties of fluorescent metal ion sensors. From the standpoint of biological imaging, ZS5 is a robust and versatile tool for illuminating $\mathrm{Zn}$ (II) uptake and mobilization in living cells, 
including neurons. Mitochondrial probe localization occurs for ZS5 in HeLa cells, in contrast to the Golgi localization of ZP3, demonstrating that ligand modifications can direct fluoresceinbased sensors to specific locales. Glutamate-dependent Zn(II) entry into embryonic hippocampal neurons was visualized, as was $\mathrm{Zn}$ (II) release from native protein stores in dentate gyrus neurons. We anticipate that ZS5, alone or in combination with high-affinity Zn(II) probes such as ZP3, will be useful for studies of Zn(II) physiology and pathology in a variety of contexts.

\title{
Supplementary Material
}

Refer to Web version on PubMed Central for supplementary material.

\begin{abstract}
Acknowledgements
This work was supported by Grant GM65519 from the National Institute of General Medical Sciences. Spectroscopic instrumentation at the MIT DCIF is maintained with funding from NIH Grant 1S10RR-13886-01 and NSF Grants CH3-9808063, DB19729592, and CHE-9808061. M.S. is an investigator of the Howard Hughes Medical Institute. E.M.N. thanks the Whitaker Health Science Fund for a graduate fellowship and Dr. D. Song for assistance with collecting the X-ray data.
\end{abstract}

\section{References}

1. Frederickson CJ, Koh JH, Bush AI. Nat Neurosci 2005;6:449-462.

2. Chang CJ, Lippard SJ. Metal Ions Life Sci 2006;1:321-370.

3. Frederickson CJ. Int Rev Neurobiol 1989;31:145-238. [PubMed: 2689380]

4. Takeda A. BioMetals 2001;14:343-351. [PubMed: 11831464]

5. "Mobile" can also refer to zinc that has been released from native protein stores.

6. Salazar G, Craige B, Love R, Kalman D, Faundez V. J Cell Sci 2005;118:1911-1921. [PubMed: 15860731]

7. Peters S, Koh J, Choi DW. Science 1987;236:589-593. [PubMed: 2883728]

8. Kim TY, Hwang JJ, Yun SH, Jung MW, Koh JY. Synapse 2002;46:49-56. [PubMed: 12211081]

9. Molnár P, Nadler JV. Brain Res 2001;910:205-207. [PubMed: 11489274]

10. Ueno S, Tsukamoto M, Hirano T, Kikuchi K, Yamada MK, Nishiyama N, Nagano T, Matsuki N, Ikegaya Y. J Cell Biol 2002;158:215-220. [PubMed: 12119362]

11. Davies PA, Wang W, Hales TG, Kirkness EF. J Biol Chem 2003;278:712-717. [PubMed: 12381728]

12. Li Y, Hough CJ, Frederickson CJ, Sarvey JM. J Neurosci 2001;21:8015-8025. [PubMed: 11588174]

13. Assaf SY, Chung SH. Nature (London) 1984;308:734-736. [PubMed: 6717566]

14. Howell GA, Welch MG, Frederickson CJ. Nature (London) 1984;308:736-738. [PubMed: 6717567]

15. Li Y, Hough CJ, Suh SW, Sarvey JM, Frederickson CJ. J Neurophysiol 2001;86:2597-2604. [PubMed: 11698545]

16. Kay AR. J Neurosci 2003;23:6847-6855. [PubMed: 12890779]

17. Qian J, Noebels JL. J Physiol 2005;566:747-758. [PubMed: 15919713]

18. Frederickson CJ, Giblin LJ, Rengarajan B, Masalha R, Frederickson CJ, Zeng Y, Lopez EV, Koh JY, Chorin U, Besser L, Herskfinkel M, Li Y, Thompson RB, Krezel A. J Neurosci Methods 2006;154:19-29. [PubMed: 16460810]

19. Kay AR. Trends Neurosci 2006;29:200-206. [PubMed: 16515810]

20. Liuzzi JP, Cousins RJ. Annu Rev Nutr 2004;24:151-172. [PubMed: 15189117]

21. Colvin RA, Fontaine CP, Laskowski M, Thomas D. Eur J Pharmacol 2003;479:171-185. [PubMed: 14612148]

22. Ebadi M, Iversen PL, Hao R, Cerutis DR, Rojas P, Happe HK, Murrin LC, Pfeiffer RF. Neurochem Int 1995;27:1-22. [PubMed: 7655341]

23. Jacob C, Maret W, Vallee BL. Proc Natl Acad Sci USA 1998;95:3489-3494. [PubMed: 9520393]

24. Choi DW, Koh JY. Annu Rev Neurosci 1998;21:347-375. [PubMed: 9530500] 
25. Lee JY, Cole TB, Palmiter RD, Koh JY. J Neurosci 2000;20:RC79 1-5. [PubMed: 10807937]

26. Lee JY, Kim JH, Palmiter RD, Koh JY. Exp Neurol 2003;184:337-347. [PubMed: 14637104]

27. Wei G, Hough CJ, Sarvey JM. Neuroscience (Oxford) 2004;125:867-877.

28. Frederickson CJ, Maret W, Cuajungco MP. Neuroscientist 2004;10:18-25. [PubMed: 14987444]

29. Mocchegiani E, Bertoni-Freddari C, Marcellini F, Malavolta M. Prog Neurobiol 2005;75:367-390. [PubMed: 15927345]

30. Bush AI. Trends Neurosci 2003;26:207-214. [PubMed: 12689772]

31. Bossy-Wetzel E, Talantova MV, Lee WD, Scholzke MN, Harrop A, Mathews E, Götz T, Han J, Ellisman MH, Perkins GA, Lipton SA. Neuron 2004;41:351-365. [PubMed: 14766175]

32. Zhang Y, Wang H, Li J, Jimenez DA, Levitan ES, Aizenman E, Rosenberg PA. J Neurosci 2004;24:10616-10627. [PubMed: 15564577]

33. Frederickson CJ, Kasarskis EJ, Ringo D, Frederickson RE. J Neurosci Methods 1987;20:91-103. [PubMed: 3600033]

34. Zalewski PD, Forbes IJ, Betts WH. Biochem J 1993;296:403-408. [PubMed: 8257431]

35. Coyle P, Zalewski PD, Philcox JC, Forbes IJ, Ward AD, Lincoln SF, Mahadevan I, Rofe AM. Biochem J 1994;303:781-786. [PubMed: 7980447]

36. Zalewski PD, Forbes IJ, Seamark RF, Borlinghaus R, Betts WH, Lincoln SF, Ward AD. Chem Biol 1994;1:153-161. [PubMed: 9383385]

37. Takahashi A, Camacho P, Lechileiter JD, Herman B. Physiol Rev 1999;79:1089-1125. [PubMed: 10508230]

38. Kimura E, Koike T. Chem Soc Rev 1998;27:179-184.

39. Kikuchi K, Komatsu K, Nagano T. Curr Opin Chem Biol 2004;8:182-191. [PubMed: 15062780]

40. Jiang P, Guo Z. Coord Chem Rev 2004;248:205-229.

41. Lim NC, Freake HC, Brückner C. Chem Eur J 2005;11:38-49.

42. Hirano T, Kikuchi K, Urano Y, Higuchi T, Nagano T. Angew Chem, Int Ed 2000;39:1052-1054.

43. Hirano T, Kikuchi K, Urano Y, Nagano T. J Am Chem Soc 2002;124:6555-6562. [PubMed: 12047174]

44. Komatsu K, Kikuchi K, Kojima H, Urano Y, Nagano T. J Am Chem Soc 2005;127:10197-10204. [PubMed: 16028930]

45. Gee KR, Zhou ZL, Qian WJ, Kennedy R. J Am Chem Soc 2002;124:776-778. [PubMed: 11817952]

46. Gee KR, Zhou ZL, Ton-That D, Sensi SL, Weiss JH. Cell Calcium 2002;31:245-251. [PubMed: 12098227]

47. Burdette SC, Walkup GK, Spingler B, Tsien RY, Lippard SJ. J Am Chem Soc 2001;123:7831-7841. [PubMed: 11493056]

48. Burdette SC, Frederickson CJ, Bu W, Lippard SJ. J Am Chem Soc 2003;125:1778-1787. [PubMed: 12580603]

49. Chang CJ, Nolan EM, Jaworski J, Burdette SC, Sheng M, Lippard SJ. Chem Biol 2004;11:203-210. [PubMed: 15123282]

50. Nolan EM, Jaworski J, Okamoto KI, Hayashi Y, Sheng M, Lippard SJ. J Am Chem Soc 2005;127:16812-16823. [PubMed: 16316228]

51. Henary MM, Wu Y, Fahrni CJ. Chem Eur J 2004;10:3015-3025.

52. Woodroofe CC, Lippard SJ. J Am Chem Soc 2003;125:11458-11459. [PubMed: 13129323]

53. Taki M, Wolford JL, O'Halloran TV. J Am Chem Soc 2004;126:712-713. [PubMed: 14733534]

54. Chang CJ, Jaworski J, Nolan EM, Sheng M, Lippard SJ. Proc Natl Acad Sci USA 2004;101:1129_ 1134. [PubMed: 14734801]

55. Kiyose K, Kojima H, Urano Y, Nagano T. J Am Chem Soc 2006;128:6548-6549. [PubMed: 16704241]

56. Thompson RB, Maliwal BP. Anal Chem 1998;70:1749-1754.

57. Thompson RB, Whetsell WO, Maliwal BP, Fierke CA, Frederickson CJ. J Neurosci Methods 2000;96:35-45. [PubMed: 10704669]

58. Thompson RB, Cramer ML, Bozym R. J Biomed Opt 2002;7:555-560. [PubMed: 12421121] 
59. Bozym RA, Thompson RB, Stoddard AK, Fierke CA. ACS Chem Biol 2006;1:103-111. [PubMed: 17163650]

60. Godwin HA, Berg JM. J Am Chem Soc 1996;118:6514-6515.

61. Walkup GK, Imperiali B. J Am Chem Soc 1996;118:3053-3054.

62. Shults MD, Pearce DA, Imperiali B. J Am Chem Soc 2003;125:10591-10597. [PubMed: 12940742]

63. Goldsmith CR, Lippard SJ. Inorg Chem 2006;45:555-561. [PubMed: 16411690]

64. Nolan EM, Lippard SJ. Inorg Chem 2004;43:8310-8317. [PubMed: 15606177]

65. Sparano BA, Shahi SP, Koide K. Org Lett 2004;6:1947-1949. [PubMed: 15176790]

66. Banerjee SR, Levadala MK, Lazarova N, Wei L, Valliant JF, Stephenson KA, Babich JW, Maresca KP, Zubieta J. Inorg Chem 2002;41:6417-6425. [PubMed: 12444786]

67. SMART: Software for the CCD Detector System, version 5.626. Bruker AXS; Madison, WI: 2000.

68. Kuzelka J, Mukhopadhyay S, Spingler B, Lippard SJ. Inorg Chem 2004;43:1751-1761. [PubMed: 14989668]

69. Sheldrick, GM. SADABS: Area-Detector Absorption Correction. University of Gottingen; Gottingen, Germany: 2001.

70. SAINTPLUS: Software for the CCD Detector System, version 5.01. Bruker AXS; Madison, WI: 1998.

71. SHELXTL: Program Library for Structure Solution and Molecular Graphics, version 6.1. Bruker AXS; Madison, WI: 2001.

72. Spek, AL. PLATON, A Multipurpose Crystallographic Tool. Utrecht University; Utrecht, The Netherlands: 2000.

73. Brannon JH, Madge D. J Phys Chem 1978;82:705-709.

74. Nolan EM, Burdette SC, Harvey JH, Hilderbrand SA, Lippard SJ. Inorg Chem 2004;43:2624-2635. [PubMed: 15074981]

75. Lim MH, Xu D, Lippard SJ. Nat Chem Biol 2006;2:375-380. [PubMed: 16732295]

76. Kröncke KD, Kolb-Bachofen V. Methods Enzymol 1999;301:126-135. [PubMed: 9919560]

77. Brewer GJ, Toricelli JR, Evege EK, Price PJ. J Neurosci Res 1993;35:567-576. [PubMed: 8377226]

78. Figiel I, Kaczmarek L. Neurochem Int 1997;31:299-240.

79. Nolan, E. M.; Lippard, S. J. Unpublished results.

80. de Silva AP, Gunaratne HQN, Gunnlaugsson T, Huxley AJM, McCoy CP, Rademacher JT, Rice TE. Chem Rev 1997;97:1515-1566. [PubMed: 11851458]

81. Sjöback R, Nygren J, Kubista M. Spectrochim Acta Part A 1995;51:L7-L21.

82. Leonhardt H, Gordon L, Livingston R. J Phys Chem 1971;75:245-249.

83. Sun WC, Gee KR, Klaubert DH, Haugland RP. J Org Chem 1997;62:6469-6475.

84. Nolan, EM.; Jaworski, J.; Racine, ME.; Sheng, M.; Lippard, SJ. Inorg Chem. published ASAP online October 31, 2006, http://dx.doi.org/10.1021/ic061137c

85. Sensi SL, Yin HZ, Carriedo SG, Rao SS, Weiss JH. Proc Natl Acad Sci USA 1999;96:2414-2419. [PubMed: 10051656]

86. Sensi SL, Ton-That D, Weiss JH. Neurobiol Dis 2002;10:100-108. [PubMed: 12127148]

87. The hippocampal cultures were prepared from prenatal rat and contain cells from the entire hippocampus. The dentate gyrus cultures were prepared from postnatal rats and contain cells only from the dentate gyrus substructure. The dentate gyrus is the region of the hippocampus rich in $\mathrm{Zn}$ (II)-filled vesicles, which makes these cultures particularly interesting from the standpoint of $\mathrm{Zn}$ (II) neurobiology.

88. Sensi SL, Canzoniero LMT, Yu SP, Ying HS, Koh JY, Kerchner GA, Choi DW. J Neurosci 1997;17:9554-9564. [PubMed: 9391010]

89. Colvin RA, Davis N, Nipper RW, Carter PA. J Nutr 2000;130:1484S-1487S. [PubMed: 10801963] 
<smiles></smiles>

$Z \mathrm{P} 1: \mathrm{X}=\mathrm{Cl}, \mathrm{Y}=\mathrm{H}$

ZP2: $\mathrm{X}=\mathrm{H}, \mathrm{Y}=\mathrm{H}$ $Z P 3: X=F, Y=H$ ZPCl1: $\mathrm{X}=\mathrm{Cl}, \mathrm{Y}=\mathrm{Cl}$ ZPF1: $X=\mathrm{Cl}, Y=F$ ZPF3: $X=F, Y=F$<smiles>[X]c1cc2c(-c3ccccc3C(=O)O)c3cc([X])c(=O)c(CN(CCSCC)Cc4ccccn4)c-3oc2c(CN(CCSCC)Cc2ccccn2)c1O</smiles>

$\mathrm{ZS1}: \mathrm{X}=\mathrm{Cl}$ ZS2: $\mathrm{X}=\mathrm{F}$

Figure 1.

Symmetrical and tertiary-amine-based Zinpyr (ZP) and Zinspy (ZS) sensors. 


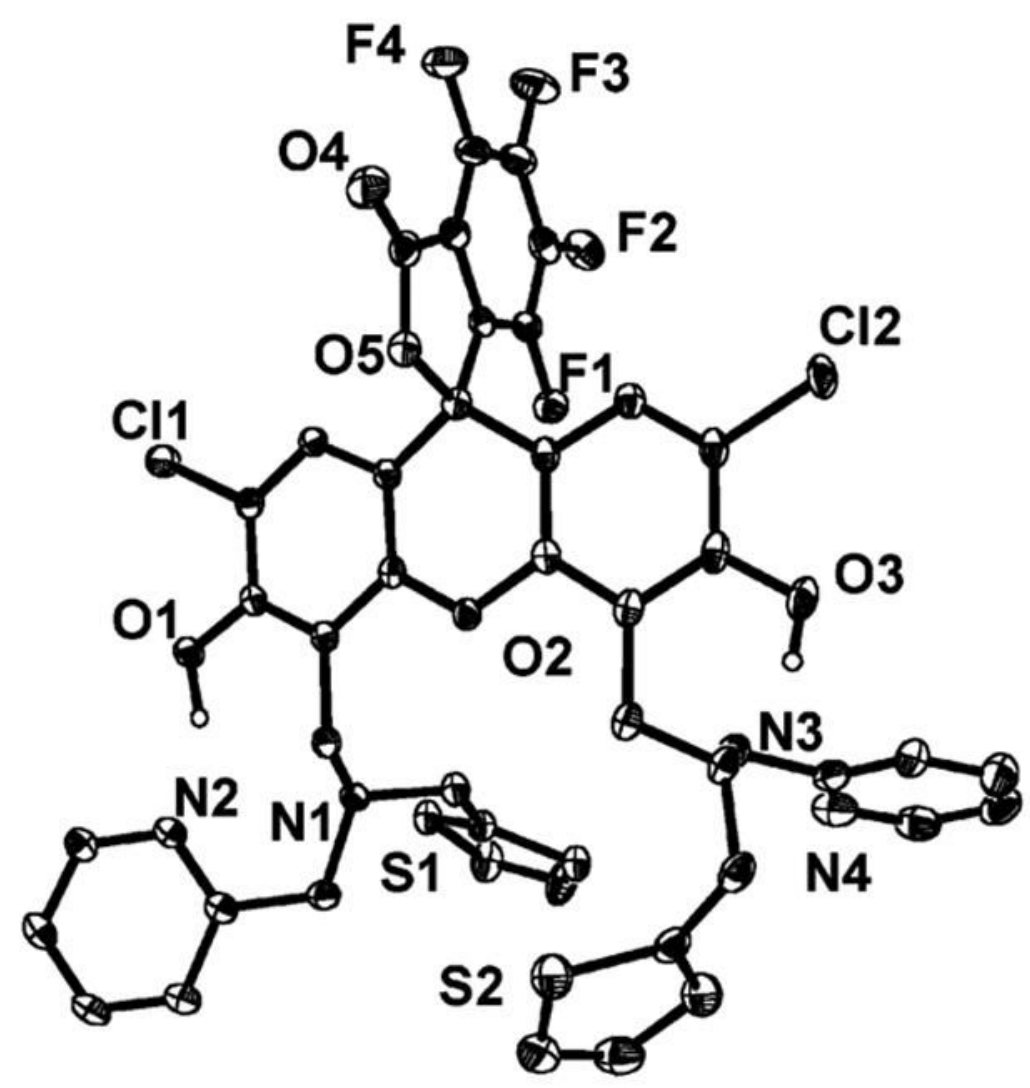

Figure 2.

ORTEP diagram for the structure of ZSF6, showing $40 \%$ probability ellipsoids on all nonhydrogen atoms. 

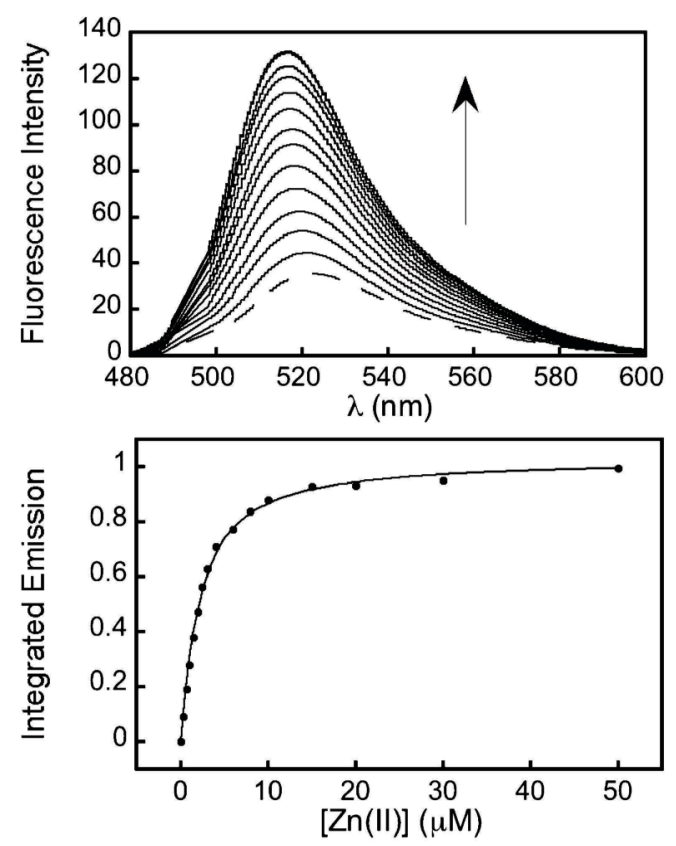

Figure 3.

Fluorescence response of $1 \mu \mathrm{M} Z \mathrm{ZS} 5$ to Zn(II). Top: Response of ZS5 to Zn(II) at pH 7 (50 mM PIPES, $100 \mathrm{mM} \mathrm{KCl}$ ) and $25^{\circ} \mathrm{C}$. Bottom: Integrated emission vs Zn(II) concentration for ZS5. Aliquots of 1 and $10 \mathrm{mM} \mathrm{ZnCl}_{2}$ were added to afford $0,0.33,0.66,1,1.5,2.0,2.5,3.0,4.0$, $6.0,8.0,10,15,20,30$, and $50 \mu \mathrm{M} \mathrm{Zn}$ (II). The circles depict the experimental data, and the line is the fit to a 1:1 metal-ligand binding model. Excitation was provided at $490 \mathrm{~nm}$. 

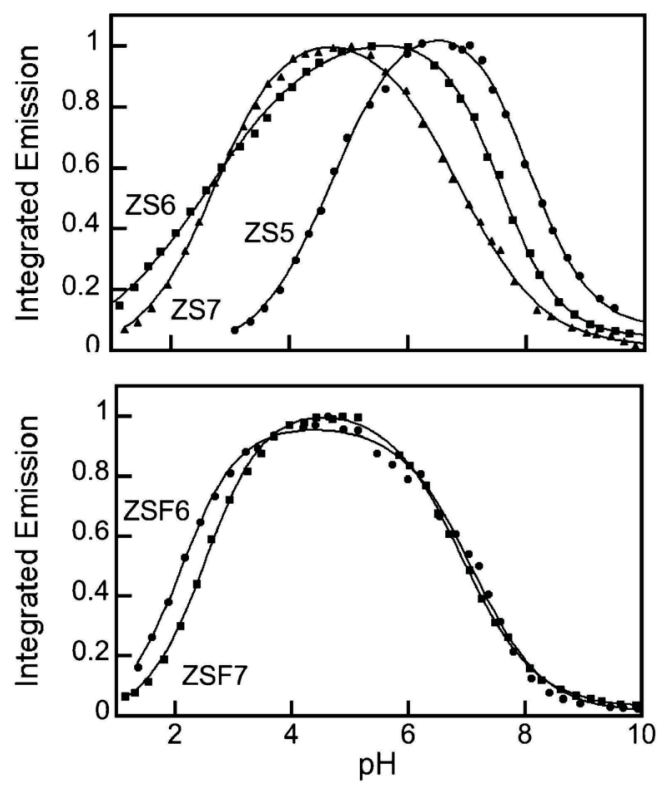

Figure 4.

Effect of $\mathrm{pH}$ on integrated emission $\left(100 \mathrm{mM} \mathrm{KCl}, 25^{\circ} \mathrm{C}\right)$. Top plot: Representative $\mathrm{pH}$ titrations for ZS5 (circles), ZS6 (squares), and ZS7 (diamonds). Bottom plot: Representative pH titrations for ZSF6 (circles) and ZSF7 (squares). For each titration, a $1 \mu \mathrm{M}$ solution of ZS was prepared $(10 \mathrm{mM} \mathrm{KOH}, 100 \mathrm{mM} \mathrm{KCl}, \mathrm{pH} \sim 12)$, and the $\mathrm{pH}$ was lowered by incremental addition of aqueous $\mathrm{HCl}$. Data for $\mathrm{pH}>12$ are excluded from the plots, since no appreciable fluorescence change occurred in this range. The $\mathrm{p} K_{\mathrm{a}}$ values, obtained from fitting the experimental data to a nonlinear model, ${ }^{47}$ are listed in Table 1. 

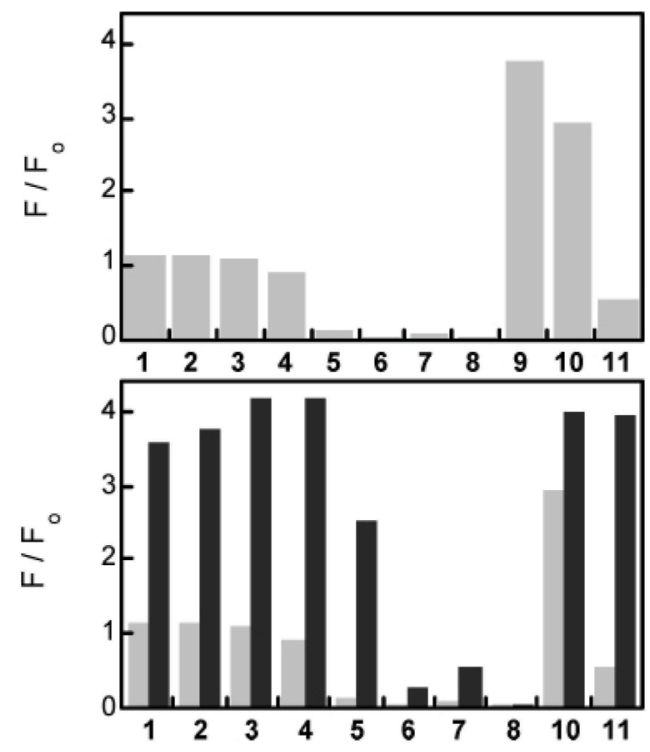

Figure 5.

Selectivity of ZS5 for Zn(II) at pH 7 (50 mM PIPES, $100 \mathrm{mM} \mathrm{KCl).} \mathrm{Top} \mathrm{plot:} \mathrm{Fluorescence}$ response of $1 \mu \mathrm{M}$ ZS5 to 50 equiv of the cation of interest: $1, \mathrm{Na}(\mathrm{I}) ; 2, \mathrm{Ca}(\mathrm{II}) ; 3, \mathrm{Mg}(\mathrm{II}) ; 4$, $\mathrm{Mn}(\mathrm{II}) ; 5$, Fe(II); 6, Co(II); 7, Ni(II); 8, Cu(II); 9, Zn(II); 10, Cd(II); 11, Hg(II). Bottom plot: The light gray bars correspond to the bars in the top plot. The black bars illustrate the fluorescence change that occurs immediately after 50 equiv of $\mathrm{Zn}(\mathrm{II})$ is added to the solution containing $1 \mu \mathrm{M}$ ZS5 and 50 equiv of the cation of interest. All data $(F)$ are normalized with respect to the emission from the free sensor $\left(F_{\mathrm{o}}\right)$. Excitation was provided at $490 \mathrm{~nm}$ and $25^{\circ}$ C. 


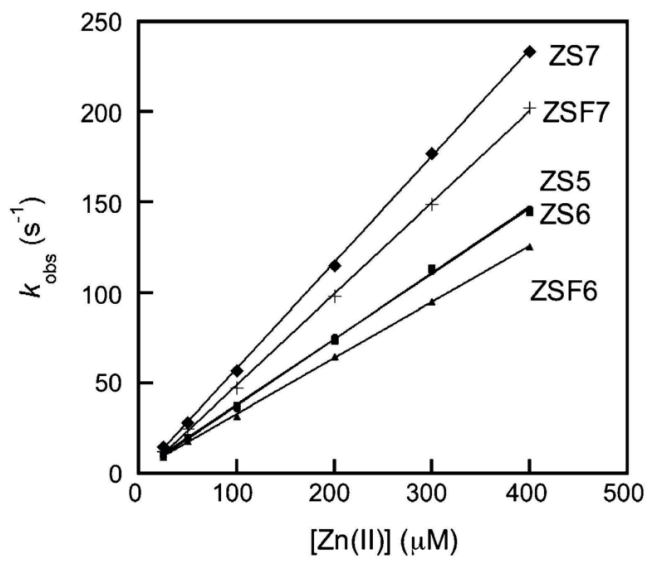

Figure 6.

Plots of $k_{\mathrm{obs}}$ vs $\mathrm{Zn}$ (II) concentration for ZS family members obtained from stopped-flow fluorescence studies at $\mathrm{pH} 7(50 \mathrm{mM}$ PIPES, $100 \mathrm{mM} \mathrm{KCl})$ and $4.3{ }^{\circ} \mathrm{C}$. The concentration of $\mathrm{ZS}$ was $0.5 \mu \mathrm{M}$ after mixing, and the concentration of $\mathrm{Zn}(\mathrm{II})$ was varied from 0 to $400 \mu \mathrm{M}$ after mixing. Experimentally determined $\mathrm{Zn}(\mathrm{II})$ association $\left(k_{\mathrm{on}}\right)$ and calculated $\mathrm{Zn}$ (II) dissociation $\left(k_{\text {off }}\right)$ rate constants are given in Table 2. 

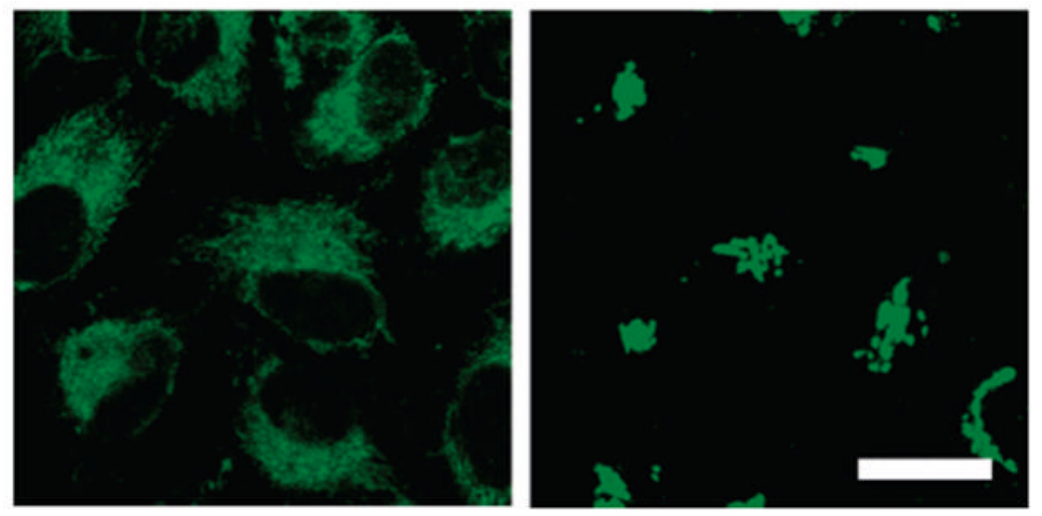

Figure 7.

Comparison of subcellular compartmentalization of ZS5 (left) and ZP3 (right) in HeLa cells. Both confocal images were obtained $5 \mathrm{~min}$ after addition of $100 \mu \mathrm{M} \mathrm{Zn(II)/pyrithione} \mathrm{to} \mathrm{cells}$ treated with $10 \mu \mathrm{M} \mathrm{ZS} 5$ or $\mathrm{ZP} 3\left(37{ }^{\circ} \mathrm{C}, 5 \% \mathrm{CO}_{2}\right)$. Addition of $\mathrm{Zn}(\mathrm{II}) /$ pyrithione has no effect on sensor localization during this time frame. The scale bar is $25 \mu \mathrm{m}$. 
A.
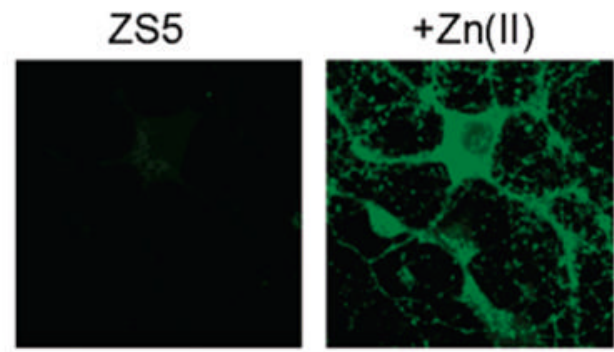

+ TPEN
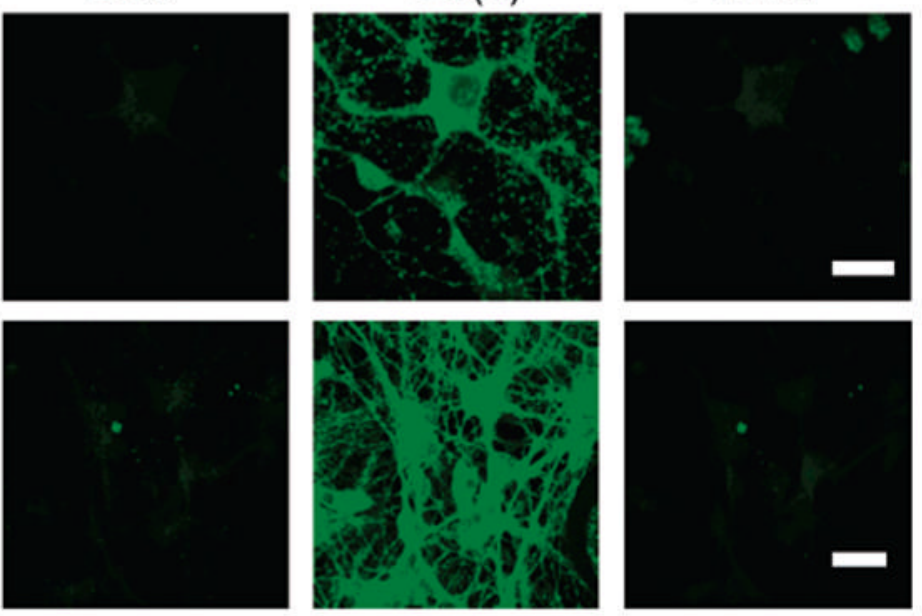

B.

\section{Figure 8.}

Response of ZS5 to exogenously added Zn(II) in primary cultures of hippocampal (row A) and dentate gyrus (row B) neurons. Left panels: Neurons were treated with $10 \mu \mathrm{M}$ ZS5 for $30 \mathrm{~min}$ $\left(37{ }^{\circ} \mathrm{C}, 5 \% \mathrm{CO}_{2}\right)$, washed, and imaged. Middle panels: Fluorescence change observed $1 \mathrm{~min}$ (hippo-campal neurons) or $5 \mathrm{~min}$ (dentate gyrus neurons) after addition of $50 \mu \mathrm{M} \mathrm{Zn(II)/}$ pyrithione (1:2 ratio). Right panels: Fluorescence decrease observed 1 min (hippocampal neurons) or $5 \mathrm{~min}$ (dentate gyrus neurons) after addition of $50 \mu \mathrm{M}$ TPEN. The scale bars represent $25 \mu \mathrm{m}$. 


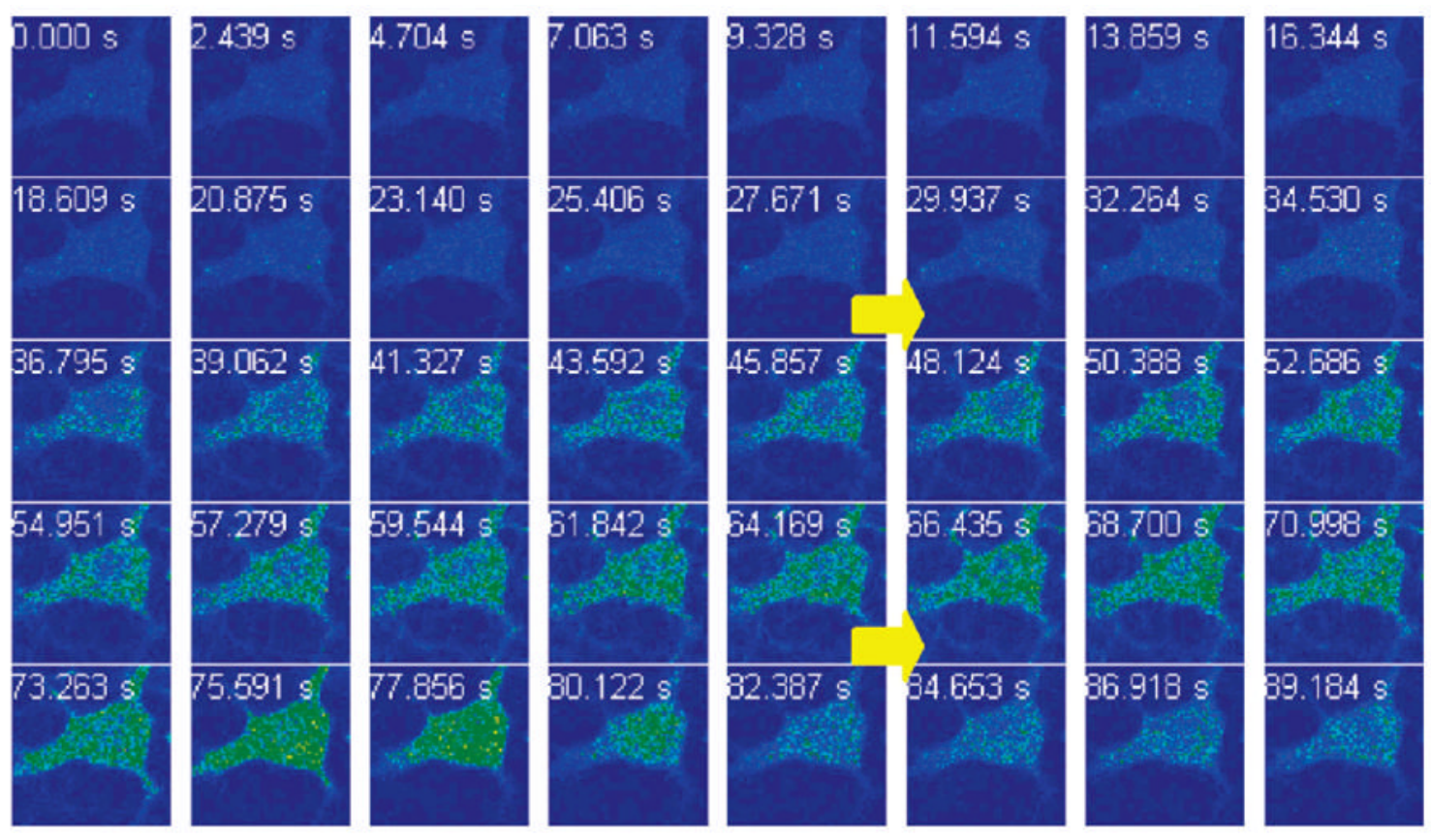

Figure 9.

Time-lapse imaging of $\mathrm{Zn}$ (II) addition to primary cultures of hippocampal neurons (DIV 18) pretreated with $10 \mu \mathrm{M}$ ZS5. The ZS5-treated cell was imaged (0-27.671 s); Zn(II)/pyrithione (50 $\mu \mathrm{M}, 1: 1$ ratio) was added during the image acquisition (29.937-34.530 s, top arrow), and a fluorescence rise is observed. An aliquot of TPEN $(50 \mu \mathrm{M})$ was subsequently added during the data collection (66.435-70.998 s, bottom arrow), and a fluorescence decrease occurred at ca. $80 \mathrm{~s}$. 

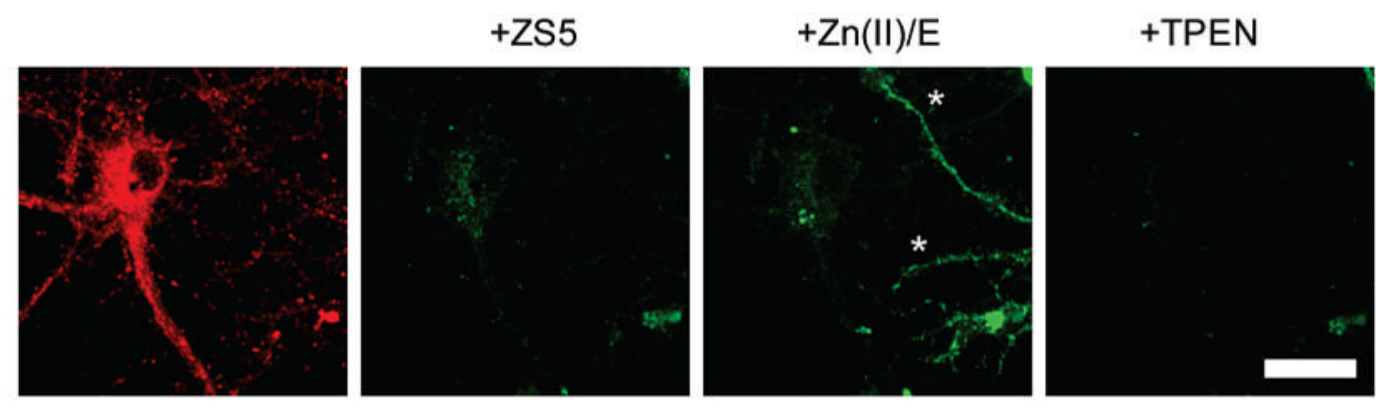

Figure 10.

Uptake of exogenous $\mathrm{Zn}$ (II) by hippocampal neurons as a result of glutamate (E) treatment. Hippocampal neurons were treated with $10 \mu \mathrm{M}$ ZS5 for $30 \min \left(37^{\circ} \mathrm{C}, 5 \% \mathrm{CO}_{2}\right)$, washed, and imaged. The neurons were treated with $50 \mu \mathrm{M}$ 1:2 $\mathrm{Zn}(\mathrm{II}) / \mathrm{E}$ and imaged $1 \mathrm{~min}$ following addition. A fluorescence rise occurs in a number of neuronal projections, labeled by asterisks. The fluorescence increase is reversed 1 min after addition of $50 \mu \mathrm{M}$ TPEN. Lysotracker Red was used as the red marker in this experiment. The scale bar represents $25 \mu \mathrm{m}$. 


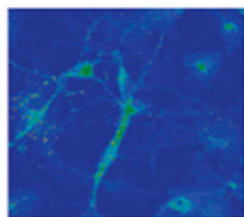

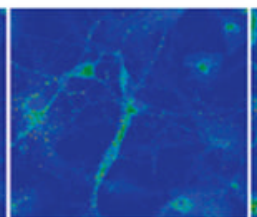

+ SNOC, 1 min

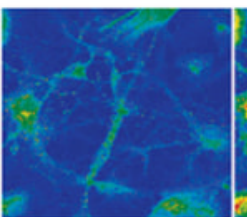

$3 \mathrm{~min}$

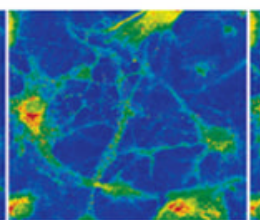

$5 \mathrm{~min}$

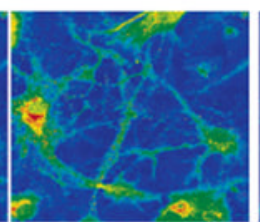

$7 \mathrm{~min}$

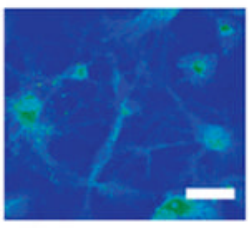

+ TPEN, 2 min

Figure 11.

Imaging endogenous $\mathrm{Zn}$ (II) release in primary dentate gyrus neuronal cultures following nitrosative stress with ZS5. The cells were treated with $10 \mu \mathrm{M}$ ZS5 $\left(30 \mathrm{~min}, 37^{\circ} \mathrm{C}, 5 \% \mathrm{CO}_{2}\right)$, washed, and imaged. An aliquot of SNOC was added (final concentration $=1.5 \mathrm{mM}$ ), and the fluorescence change was recorded at 1-min intervals. Time points for $0,1,3,5$, and 7 min are shown above. The right-most panel shows the fluorescence decrease that occurred 2 min after addition of $200 \mu \mathrm{M}$ TPEN. The scale bar indicates $25 \mu \mathrm{m}$. 

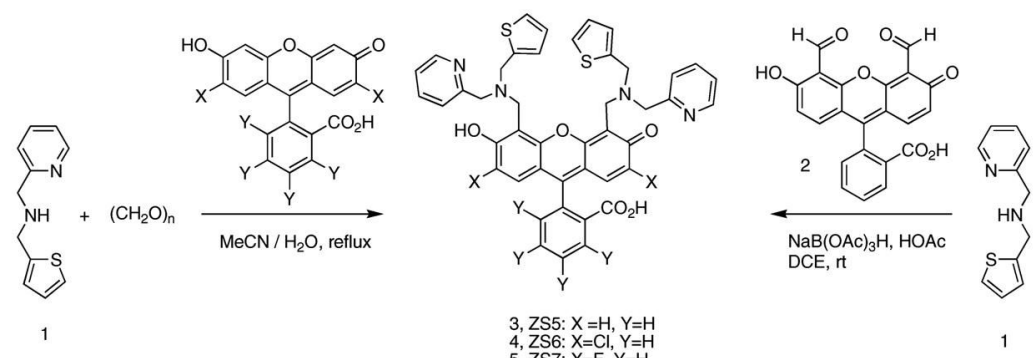

3, ZS5: $X=\mathrm{H}, \mathrm{Y}=\mathrm{H}$
4, ZS6: $\mathrm{X}=\mathrm{Cl}, \mathrm{Y}=\mathrm{H}$

5, ZST: $X=F, Y=H$

6, ZSCI6: $X=C l, Y=C$
7, ZSFG: $X=C l, Y=F$
8. $Z S F 7: X=F, Y=F$

Scheme 1. 


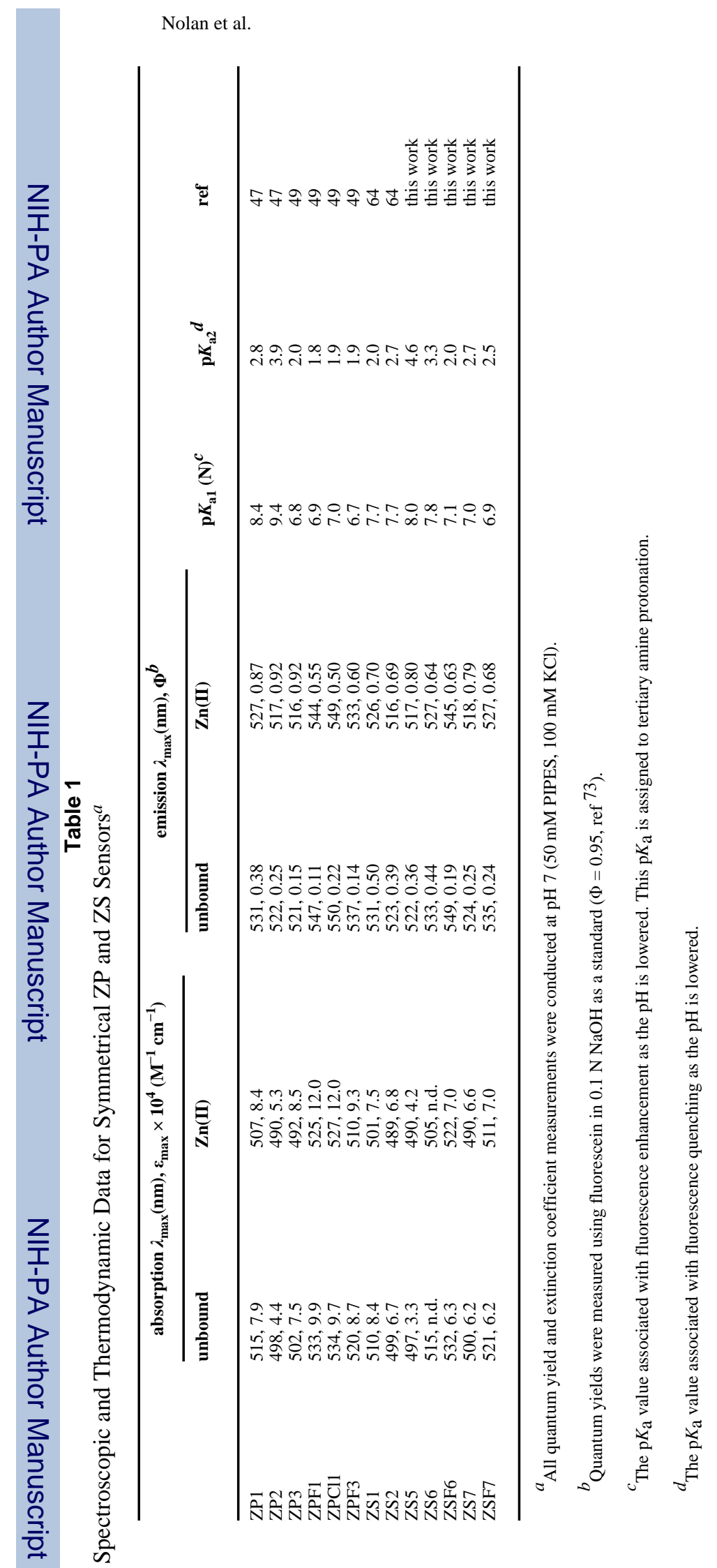

J Am Chem Soc. Author manuscript; available in PMC 2007 October 9. 


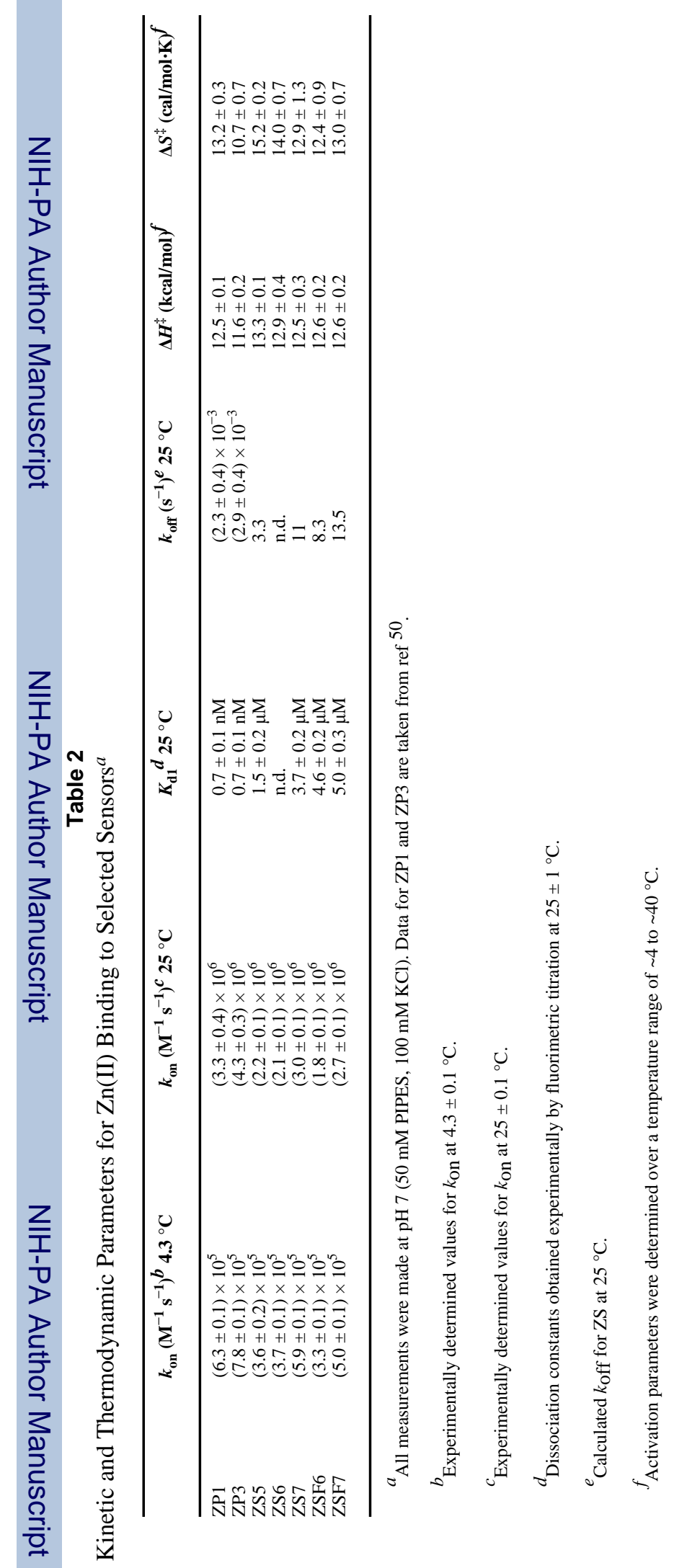




\section{Table 3}

Cytotoxicity Data (HeLa, 24 h) ${ }^{a}$

\begin{tabular}{lrcl}
\hline & & \% cell survival & \\
\cline { 2 - 4 } & $\mathbf{1} \boldsymbol{\mu} \mathbf{M}$ & $\mathbf{5} \boldsymbol{\mu} \mathbf{M}$ & $\mathbf{1 0} \boldsymbol{\mu} \mathbf{M}$ \\
\hline ZP1 & $96 \pm 2$ & $68 \pm 5$ & $40 \pm 6$ \\
ZP3 & $93 \pm 4$ & $73 \pm 8$ & $57 \pm 13$ \\
ZS5 & $101 \pm 1$ & $87 \pm 2$ & $80 \pm 4$ \\
\hline
\end{tabular}

${ }^{a}$ Cell viability was quantified by the MTT assay (mean \pm SD). 